Volume 111

Issue 2 Dickinson Law Review - Volume 111, 2006-2007

$10-1-2006$

\title{
Originalism, the Declaration of Independence, and the Constitution: A Unique Role in Constitutional Interpretation?
}

Lee J. Strang

Follow this and additional works at: https://ideas.dickinsonlaw.psu.edu/dlra

\section{Recommended Citation}

Lee J. Strang, Originalism, the Declaration of Independence, and the Constitution: A Unique Role in Constitutional Interpretation?, 111 DICK. L. REV. 413 (2006).

Available at: https://ideas.dickinsonlaw.psu.edu/dlra/vol111/iss2/5

This Article is brought to you for free and open access by the Law Reviews at Dickinson Law IDEAS. It has been accepted for inclusion in Dickinson Law Review by an authorized editor of Dickinson Law IDEAS. For more information, please contactlja10@psu.edu. 


\title{
Originalism, the Declaration of Independence, and the Constitution: A Unique Role in Constitutional Interpretation?
}

\author{
Lee J. Strang*
}

\section{Introduction}

The role of the Declaration of Independence in constitutional interpretation is contested. Some argue that it is "at the heart of the Constitution," that the Declaration "is fundamental to a proper understanding of the Constitution,"2 and that Americans should interpret "the Constitution through the lens of the Declaration." I will refer to scholars such as these, who argue that the Declaration should play a unique role in constitutional interpretation, as Declarationists. ${ }^{4}$

Others have argued that "the Declaration as the meaning of the Constitution is almost incomprehensible" because "the Declaration of Independence has no standing in constitutional interpretation

* Assistant Professor of Law, Ave Maria School of Law. I would like to thank my loving wife Elizabeth for her sacrifice to allow me to write this Article. I would also like to thank the participants at the Ave Maria Faculty Workshop who offered their input, the participants at the 2006 University Faculty For Life Conference for their suggestions, Bryce Poole, Justin Gardner, Tim Kuhn, Travis Comstock, and Stephen Burch for their research assistance, and especially Howard Bromberg whose enthusiasm for the Declaration of Independence was the impetus for this Article.

1. Scott Douglas Gerber, To Secure These Rights: The Declaration of INDEPENDENCE AND CONSTITUTIONAL INTERPRETATION 3 (1995).

2. Dan Himmelfarb, Note, The Constitutional Relevance of the Second Sentence of the Declaration of Independence, 100 Y ALE L.J. 169, 170 (1990).

3. Timothy Sandefur, Liberal Originalism: A Past for the Future, 27 HARV. J.L. \& PUB. POL'Y 489, 505 (2004).

4. Declarationists are those who believe that the Declaration's role in constitutional interpretation is greater than its role as a source of the Constitution's original meaning.

5. Patrick M. O'Neil, The Declaration as Ur-Constitution: The Bizarre Jurisprudential Philosophy of Professor Harry V. Jaffa, 28 AKRON L. REV. 237, 252 (1995). 
whatsoever." As Justice Scalia has stated more critically: "If you want aspirations, you can read the Declaration of Independence. . . . There is no such philosophizing in our Constitution, which, unlike the Declaration of Independence ... is a practical and pragmatic charter of government."7

In this Article, I argue that the Declaration of Independence is one of many sources of the Constitution's original meaning. First, I discuss the background debate over the role of the Declaration in constitutional interpretation and how appeals to the Declaration have periodically arisen during times of national moral crisis, such as those over slavery and civil rights. I also detail how scholars have relied on the Declaration to support dramatically inconsistent claims of political morality and constitutional norm.

Assuming an originalist perspective on constitutional interpretation, ${ }^{8}$ I then argue that the historical evidence from the Framing and Ratification of the Constitution shows that the Declaration is simply one source of the original meaning of the Constitution. ${ }^{9}$ In addition, I show that the Declaration is not the "interpretative key" to the Constitution because they are inconsistent, and because the Declaration cannot provide sufficient interpretative guidance. Lastly, I advance arguments to establish that the Declaration is not legally binding. In doing so, I rebut many of the common Declarationist claims. ${ }^{10}$

\section{Debate Over the Role of the Declaration of Independence in} Constitutional Interpretation

\section{A. Introduction}

Part II will review the debate, both past and present, over what role, if any, the Declaration should have in constitutional interpretation. ${ }^{11}$

6. Interview by Lewis E. Lehrman with Benno Schmidt, quoted in Lewis E. Lehrman, On Jaffa, Lincoln, Marshall, and Original Intent, in HARRY V. JAFFA ET AL., ORIGINAL INTENT AND THE FRAMERS OF THE CONSTITUTION 3, 5 (1994).

7. ANTONIN Scalia, A MatTer of InTERPRetation: Federal Courts and the LAW 134 (1997).

8. I assume an originalist perspective because most Declarationists are originalists or make originalist arguments, because originalism is a major theory of constitutional interpretation, and because I believe that originalism is correct.

9. Because of space constraints, and because Declarationists infrequently rely on it, I will only note in passing the historical evidence from the "Reconstruction Constitution," that is, the changes to the Constitution brought about during the period of Reconstruction.

10. One of the purposes of this Article is to respond to relatively weak originalist claims that the Declaration should play a unique role in constitutional interpretation. In doing so, I hope to prevent the discrediting of stronger originalist arguments and, in the long run, to strengthen originalism by advancing the strongest legal arguments on its behalf.

11. For background on the drafting of the Declaration see ALLEN JAYNE, 
First, I describe how appeals to the Declaration have ebbed and waned, and how, during periods of great moral introspection, such appeals multiplied. ${ }^{12}$ Second, I show how scholars and others have varied dramatically in their view of the Declaration's role in constitutional interpretation. Third, I recount how Declarationists themselves have come to radically divergent conclusions regarding the practical impact of the Declaration playing a unique role in constitutional interpretation. Many of today's Declarationists, like some Americans in the past, use the Declaration to advance their respective views on policy and constitutional meaning. Therefore, I will discuss how the Declaration was viewed throughout our nation's history to show that today's Declarationists are continuing an old tradition. ${ }^{13}$

\section{B. Periodic Resurgence of Appeals to the Declaration in Times of Grave Moral Crisis}

\section{The "Original" Declaration}

The Declaration of Independence is one of the most revered documents in American history, ${ }^{14}$ and as a result, various political movements have appealed to it in order to garner support for the movement's proposed reforms - especially when the Constitution is widely thought to be at odds with or indifferent to the political goals of the social reformers. This is in contrast to how the document was viewed in the period following separation from Britain.

Originally, the Declaration was viewed primarily as a "proclamation of independence." 15 It provided the colonies with the moral and political justifications for separating from Great Britain. Rather than focusing on the rights phrase ${ }^{16}$ in the Declaration's second paragraph-as today's

JefFerson's Declaration of Independence: Origins, Philosophy, \& Theology (1998); Pauline MaIer, American SCRIPTURe: Making the Declaration of INDEPENDENCE (1998); GARRY WILLS, INVENTING AMERICA: JEFFERSON'S DECLARATION OF INDEPENDENCE (2002).

12. See Charles H. Cosgrove, The Declaration of Independence in Constitutional Interpretation: A Selective History and Analysis, 32 U. RICH. L. REV. 107 (1998) (providing an overview of appeals to the Declaration).

13. See infra Part III.B.1.c.

14. One can see this, for instance, in the titles of popular books on the Declaration such as those by Wills, Inventing America, and Maier, American Scripture.

15. Philip F. Detweiler, The Changing Reputation of the Declaration of Independence: The First Fifty Years, 19 WM. \& MARY Q. 557, 558 (1962); see also MAIER, supra note 11, at 154-208 (describing the change in public attitudes towards the Declaration).

16. The rights phrase is a phrase in the second paragraph of the Declaration: "that all men are created equal, that they are endowed by their Creator with certain un-alienable 
Declarationists do- the contemporaries of the document focused both on its conclusion, which declared to the world that the thirteen colonies were independent, ${ }^{17}$ and on the specific charges lodged against King George III in the Declaration's body. ${ }^{18}$ In addition, unlike today's Declarationists, when early Americans discussed natural rights and referred to a document to support their claims, the document to which they most often referred was the Virginia Declaration of Rights, not the Declaration. $^{19}$

At first, in the years following independence, little attention was paid to the Declaration. ${ }^{20}$ Such silence towards the Declaration is understandable since the task facing the nation was no longer revolution, but rather the construction of a new legal order. ${ }^{21}$ But silence regarding the Declaration was short-lived. Once the dust settled and a new legal order was firmly established, social reformers could not resist using the rights phrase to further their political causes. As one Declarationist scholar recognized, "a national political movement brought the Declaration of Independence 'back into American life.",22 By the 1820s, "the Declaration's newfound status as a sacred document made it extremely useful for causes attempting to seize the moral high ground in public debate." 23

The different reform movements discussed below each used the Declaration in different ways. ${ }^{24}$ On one end of the spectrum were those

Rights, that among these are Life, Liberty and the pursuit of Happiness." THE DECLARATION OF INDEPENDENCE para. 2 (U.S. 1776).

17. Detweiler, supra note 15 , at 558 .

18. For example, during the ratification process of the Articles of Confederation, New Jersey explained its reservations concerning Article VI. Article VI provided that Congress would determine when to station troops in a state for purposes of protecting the state. THE ARTICLES OF CONFEDERATION, art. VI (1781). New Jersey sought to require the assent of nine states for the keeping of a "Body of Troops" because the constant upkeep of troops ran counter to the Declaration:

In the memorable Act of Congress, declaring the United Colonies free and independent States, it is emphatically mentioned, as one of the Causes of Separation from Great-Britain, that the Sovereign thereof had kept up among us in Time of Peace, standing Armies without the Consent of the Legislatures.

1 Merrill Jensen, The Documentary History of the Ratification of the CONSTITUTION: CONSTITUTIONAL DOCUMENTS AND RECORDS, 1776-1787, 114 (1976).

19. Detweiler, supra note 15, at 561-62.

20. MAIER, supra note 11, at 168-69.

21. See MAIER, supra note 11, at 212 ("The predicament of preserving a nation that formally began with a revolutionary manifesto ... fell to the Federalists in the 1790s. Their solution was to forget the Declaration of Independence.").

22. Robert J. Reinstein, Completing the Constitution: The Declaration of Independence, Bill of Rights and Fourteenth Amendment, 66 TEMP. L. REV. 361, 378-79 (1993) (citation omitted).

23. MAIER, supra note 11 , at 197.

24. The movements below may not be the entire universe of major social movements 
who argued that the Declaration, and especially its rights phrase, embodied the ideals of the Republic and that the law should be changed to correspond to those ideals. On the other end were those who claimed that the Declaration, either of its own accord or through its influence on the Constitution's meaning, had already effected the legal goal(s) of the reform movement by, for example, outlawing slavery. Of course, as reform movements, they represented a minority position trying to change the status quo.

\section{Abolition Movement}

The first social movement to extensively rely on the Declaration of Independence was the abolition movement. The Constitution by itself was widely seen as inadequate to accomplish the goals of the abolitionists because, as explained below, it explicitly accommodated slavery. ${ }^{25}$ In order to legitimize the antislavery movement, abolitionists turned to the Declaration's rights phrase.

Mainstream abolitionists considered the Declaration to be the ultimate expression of America's founding principles. They viewed it as the primary document of the nation's founding which the Constitution was ratified to preserve. Thus, the Constitution, although allowing slavery, was ratified with a view towards its gradual elimination. Other, more radical abolitionists took the view that the Declaration had abolished slavery or at least rendered it unconstitutional for the federal government to support slavery. The most radical abolitionists used the Declaration as a moral justification for their actions, which, for some, included overthrowing the unjust constitutional order that sanctioned slavery. ${ }^{26}$

According to abolitionist James G. Birney, if the Constitution recognized and protected slavery's continued existence and extension to other territories, "then the Constitution and the Declaration of Independence were irreconcilable."27 Birney refused to accept this proposition:

To suppose, said Birney, before the dust and sweat of the Revolution was well wiped away from those men, that they would falsify the principles for which they risked their lives, in consenting to fasten

to use the Declaration.

25. See infra Part III.A.2 (discussing the tensions between the Declaration and the Constitution).

26. See Cosgrove, supra note 12, at 117-18 (giving these three divisions of the abolitionist movement).

27. DWight Lowell Dumond, Antislavery Origins of the Civil War In the UNITED STATES 73 (1959). 
slavery forever on the weakest of their fellow creatures on manwoman-child-and even the infant yet unborn-is what I will not do, except on testimony that cannot be overthrown--testimony that I have never yet seen or heard. ${ }^{28}$

For Birney, the principles of the Declaration were a fundamental part of the nation's laws, thus, the Constitution was drafted with the expectation that slavery would be "speedily abolished."29

Birney's conception of how the Constitution and the Declaration interacted represented the mainstream view among abolitionists prior to the Civil War. Abraham Lincoln ${ }^{30}$ emphasized the importance of the Union and the Constitution when he summarized this view:

Without the Constitution and the Union, we would not have attained the result; but even these, are not the primary cause of our great prosperity. There is something back of these, entwining itself more closely about the human heart. That something, is the principle of "Liberty to all"- the principle that clears the path for all-gives hope to all-and, by consequence, enterprise, and industry to all.

The expression of that principle, in our Declaration of Independence, was most happy, and fortunate. Without this, as well as with it, we could have declared our independence of Great Britain; but without it, we could not, I think, have secured our free government, and consequent prosperity. No oppressed people will fight, and endure, as our fathers did, without the promise of something better, than a mere change of masters.

The assertion of that principle, at that time, was the word, "fitly spoken" which has proved an "apple of gold" to us. The Union and the Constitution, are the picture of silver, subsequently framed around it. The picture was made, not to conceal, or destroy the apple; but to adorn, and preserve it. The picture was made for the applenot the apple for the picture. ${ }^{31}$

Thus, for Birney, Lincoln, and many others who advocated for the prevention of slavery's spread and for the gradual emancipation of slaves where it was already established, the Declaration of Independence proclaimed the motivating principle, the natural law impetus, behind the

28. Id. at $72-73$ (quotations omitted).

29. Id.

30. For further discussion of Lincoln's use of the Declaration, see ALLEN C. Guelzo, Abraham LinCOLN: RedeEmer PrEsident 191-98 (1999).

31. Abraham Lincoln, Fragment on the Constitution and the Union, in IV THE Collected Works of ABraHAM Lincoln 168-69 (Roy P. Basler ed., 1953) (emphases deleted). 
establishment of the United States. Although slavery was recognized in the Constitution, this was a compromise made to secure union among the states. Thus, the Constitution allowed slavery, but it was drafted with a view towards slavery's ultimate demise. ${ }^{32}$

Some abolitionists did not think Lincoln and the other "gradualists" went far enough in their approach to ending slavery. For these abolitionists, not only was slavery inconsistent with the founding natural law principles of the United States expressed in the Declaration, but the federal government was legally prohibited from recognizing slavery. According to Joshua R. Giddings, since many of the Founding Fathers abhorred slavery they were careful not to put anything in the Constitution which legitimated it. ${ }^{33}$ Giddings did not go so far as to say that the Declaration and the Constitution abolished slavery within the slave states, but he was willing to say that the federal government could not constitutionally aid the slave states in recovering escaped slaves. ${ }^{34}$ Doing so would imply that the federal government considered slaves to be property, which Giddings found to be inconsistent with the principles of the Declaration that the Constitution was drafted to secure. ${ }^{35}$

Abolitionist Lysander Spooner went further than Giddings in his views on the Declaration's effect on slavery. Spooner published a book in 1845 entitled, The Unconstitutionality of Slavery. ${ }^{36}$ He started by focusing on the Declaration's phrase, "self-evident truth." He argued that all "self-evident truths" are necessarily incorporated into all "constitutions, compacts and systems of government," if only by implication. ${ }^{37}$ This is so, because it is impossible "to enumerate all the 'self-evident truths' which must be acted upon in the administration of law." 38 Therefore, such truths are "all taken for granted, unless particular ones" are expressly denied. ${ }^{39}$ Provided that it is a "self-evident truth"

32. Philip S. Paludan, a Crisis of Republicanism: American Politics in the Civil WAR ERA 77-79 (Lloyd E. Ambrosius ed., 1990).

33. Joshua R. Giddings, Payment for Slaves, Speech of Mr. J.R. Giddings, of Ohio, on the Bill to Pay the Heirs of Antonio Pacheco for Slaves Sent West of the Mississippi with the Seminole Indians in 1838, 1-5 (Buell \& Blanchard 1849), available at http://dlxs.library.cornell.edu/m/mayantislavery/browse_G.html; see also ALBERT Bushnell Hart, American Statesmen: Salmon Portland Chase 65 (Houghton Mifflin Co. 1899).

34. Giddings, supra note 33.

35. Id.

36. Lysander Spooner, THe Unconstitutionality of Slavery 42 (Bela Marsh 1845). For a review of Spooner's arguments and his theory of constitutional interpretation see Randy E. Barnett, Was Slavery Unconstitutional Before the Thirteenth Amendment?: Lysander Spooner's Theory of Interpretation, 28 PAC. L.J. 977 (1996).

37. SPOONER, supra note 36 , at 37.

38. Id. at 43.

39. Id. 
that "all men have a natural and inalienable right to life, liberty and the pursuit of happiness, that truth constitutes a part of all our laws and all our constitutions, unless it has been unequivocally and authoritatively denied." ${ }^{40}$ Spooner went on to argue that this truth had never been denied by any law or constitution in the United States. ${ }^{41}$ Thus, in Spooner's mind, the natural law principles elucidated in the Declaration were incorporated into the Constitution by default. ${ }^{42}$

Other abolitionists appealed to the Declaration to justify their willingness to sacrifice the Union and the Constitution in order to reach their ultimate goal of immediate and unconditional emancipation. ${ }^{43}$ For example, Fredrick Douglass referred to the Declaration in a speech at Rochester, New York, to observe American independence. ${ }^{44}$ Douglass did not discuss the legal effect of the Declaration or its interaction with the Constitution. ${ }^{45}$ Instead, Douglass' references to the Declaration were made to point out the two-facedness of the American people. ${ }^{46}$ His argument against slavery was moral, and the Declaration was useful to him because the principles it declared were inconsistent with slavery and

40. Id. at 44 .

41. Id.

42. Spooner offered a second argument why slavery was unconstitutional. He began with the proposition that the Declaration was "the constitutional law of this country for certain purposes" which included absolving "people from their allegiance to the English crown." SPOONER, supra note 36 , at 42 . Thus, if it was constitutional law for that purpose, it must also be such for the "purpose of recognizing and establishing, as law, the natural and inalienable right of individuals to life, liberty and the pursuit of happiness [.]" SPOONER, supra note 36 , at 42 . In his mind, since the separation from England was lawful because of the Declaration, the principles it referred to in order to legalize the act must have been law. Spooner continued:

It is sufficient for our purpose, if it be admitted that this principle was the law of the country at that particular time, (1776) even though it had continued to be the law only for a year, or even a day. For if it were the law of the country even for a day, it freed every slave in the country - (if there were, as we say there were not, any legal slaves then in the country.) And the burden would then be upon the slaveholder to show that slavery had since been constitutionally established. And to show this, he must show an express constitutional designation of the particular individuals, who have since been made slaves. Without such particular designation of the individuals to be made slaves, (and not even the present constitutions of the slave States make any designation,) all constitutional provisions, purporting to authorize slavery, are indefinite, and uncertain in their application, and for that reason void.

SPOONER, supra note 36 , at $42-43$.

43. See William S. MCFeely, Frederick Douglass 192 (Norton 1991) (describing an 1849 speech where Douglass "endorse[d] violence"); see also id. at 211.

44. Frederick Douglass, What to the Slave is the Fourth of July? (1852), in AUTOBIOGRAPHIES 431-35 (Penguin Books USA 1994).

45. See id. at 432.

46. See id. ("I do not hesitate to declare, with all my soul, that the character and conduct of this nation never looked blacker to me than on this Fourth of July."). 
made Americans look like base hypocrites. ${ }^{47}$ According to Douglass, the Union's accommodation of slavery justified its dissolution. ${ }^{48}$

Like Douglass, abolitionist William Lloyd Garrison appealed to the Declaration to justify dissolution of the Union. ${ }^{49}$ Garrison did not use the Declaration to reinterpret the Constitution or search for antislavery principles behind the Constitution. ${ }^{50} \mathrm{He}$ regarded this as "naive wordplay or deceptive political contrivance." 51 Instead, Garrison rejected the entire constitutional compact:

By the infamous bargain which the [Founders] made between themselves, they virtually dethroned the Most High God, and trampled beneath their feet their own solemn and heaven-attested Declaration, that all men are created equal, and endowed by their Creator with certain inalienable rights-among which are life, liberty, and the pursuit of happiness. They had no lawful power to bind themselves, or their posterity, for one hour-for one moment-by such an unholy alliance.... A sacred compact! A sacred compact! What, then, is wicked and ignominious? ${ }^{52}$

For Garrison, the principles elucidated in the Declaration of Independence rendered the Constitution and its compromise with slavery illegitimate. $^{53}$

\section{Women's Suffrage Movement}

About the time the antislavery movement reached its peak, the spirit of reformism it fostered led to the birth of the women's suffrage movement. ${ }^{54}$ As with the abolitionist movement, there was a spectrum of views among the suffragettes regarding the Declaration. Some used the Declaration as rhetorical and moral support for their arguments, while

47. See id. at 434 ("To him, your celebration is a sham; your boasted liberty, an unholy license; your national greatness, swelling vanity; your sounds of rejoicing are empty and heartless; your denunciations of tyrants, brass-fronted impudence; your shouts of liberty and equality, hollow mockery. ...").

48. Douglass later recanted his goal of dissolution. FrEDERICK DOUGLASS, LifE AND TIMES OF FREDERICK DOUGLASS, in AUTOBIOGRAPHIES, supra note 44, at 704-05.

49. See William Lloyd Garrison, Address to the Colonization Society (July 4, 1829), available at $\mathrm{http} / / /$ teachingamericanhistory.org/library/index.asp?document $=562$.

50. See Henry Mayer, All on Fire: William Lloyd Garrison and the ABolition of Slavery 326-27 (St. Martin's Press 1998).

51. Id.

52. William Lloyd Garrison, On the Constitution and the Union, The Liberator, December 29, 1832, at 207, available at http:/www.fair-use.org/the-liberator/1832/ $12 / 29$ /on-the-constitution-and-the-union.

53. See id.

54. See Judith E. Harper, Susan B. Anthony: A Biographical Companion 8-9 (ABC-CLIO, Inc. 1998) (recounting Susan B. Anthony's life as passionate abolitionist and the merging of the fight for abolition and women's suffrage). 
others saw it as an independent source of binding constitutional principles. ${ }^{55}$ Although the women's suffrage movement sought a constitutional amendment to secure their right to vote, a significant portion of the suffragettes believed such an amendment was legally unnecessary because the Constitution already recognized such a right because of the Declaration. ${ }^{56}$

The first major event in the women's suffrage movement was the Seneca Falls Convention of $1848 .{ }^{57}$ For the convention, Elizabeth Cady Stanton drafted a Declaration of Sentiments, ${ }^{58}$ the preamble of which parroted the Declaration but with the addition of "women." It preamble was followed by eighteen grievances against "man," which was the same number advanced against the British King in the original Declaration. ${ }^{60}$ The Declaration of Sentiments ended with a demand for equal "rights and privileges" for women. ${ }^{61}$

Not only did the women's suffrage advocates utilize arguments based on the principles of the Declaration to gain moral and political legitimacy in their fight to amend the Constitution, ${ }^{62}$ but many also considered the Declaration to be the key to interpreting the Constitution. ${ }^{63}$ For many advocates, amending the Constitution to secure women's right to vote was unnecessary. ${ }^{64}$ This was because Stanton and other women's rights advocates were influenced by abolitionist Lysander Spooner's theory of constitutional interpretation.

The speeches of Susan B. Anthony, especially her Declaration of the Rights of Woman, exemplify this view of the interaction between the Constitution and the Declaration. She delivered her declaration outside of Independence Hall in Philadelphia during the Centennial Exposition

55. Susan B. Anthony, Is it a Crime for a United States Citizen to Vote? (1873), in HARPER, supra note 54, at 278-285.

56. Id.

57. Ellen Carol DuBois, Feminism and Suffrage: The Emergence of an INDEPENDENT WOMEN'S MOVEMENT IN AMERICA, 1848-1869, at 23 (Cornell University Press 1978).

58. Elizabeth Cady Stanton, A History of Woman Suffrage $170-71$ (Stanton et al. eds., Fowler \& Wells 1881), available at http://www.closeup.org/sentimnt.htm.

59. Id.

60. Bruce Miroff, ICONS of Democracy: American Leaders as Heros, ARISTOCRATS, DisSENTERS, AND DEMOCRATS 130 (University Press of Kansas 2000) (1993).

61. STANTON, supra note 58 , at 70-71.

62. LINDA K. KERBER, NO CONSTITUTIONAL Right TO BE LADIES: WOMEN AND THE Obligations OF CitIZENSHIP 81-92 (Hill \& Wang 1998) (recounting the campaign by Abby and Julia Smith who refused to pay their taxes in 1869 because they were paying higher taxes than all of their neighbors but without a vote in taxation decisions).

63. Susan B. Anthony, Declaration of the Rights of Woman (July 4, 1876), in HARPER, supra note 54, at 287-90.

64. See HARPER, supra note 54, at 278-285. 
of July 4, $1876 .^{65}$ Anthony argued that the natural law principles elucidated in the Declaration were the animating principles behind the Constitution and that these principles secured the right to vote for all citizens, including women. ${ }^{66}$ Anthony more explicitly stated this view in a speech she gave prior to her trial for unlawfully voting in an election. ${ }^{67}$

\section{Civil Rights Movement}

The civil rights movement was born to secure for newly-freed black Americans the same rights and privileges enjoyed by whites. ${ }^{68}$ It drew its inspiration from the Declaration of Independence, which had given impetus to the movement to end slavery and which propelled the women's suffrage movement, especially in the beginning. ${ }^{69}$ However, historical circumstances were such that over time clearly recognized laws, including the Fourteenth Amendment and the Civil Rights Act, eclipsed the Declaration in legal arguments made in support of the modern civil rights movement. ${ }^{70}$ While some proponents of the modern civil rights movement believed that the Declaration constituted binding constitutional law, or at least contained foundational principles that the Constitution was drafted to secure, references to the Declaration were relatively less frequent. ${ }^{71}$ Furthermore, the Declaration no longer constituted the primary basis of the argument for the legal reforms

65. Id. at 68 .

66. Id. at $287-90$.

67. Id. at 278-285; see also AN ACCOUNT OF THE PROCEedINGS ON THE TRIAL OF Susan B. ANTHONY, ON the Charge of Illegal Voting, at the Presidential ELECTION IN NOV. 1872 AND ON THE TRIAL OF BEVERLY W. JONES, EDWIN T. MARSH AND William B. HALL, THE INSPECTORS OF ELECTION BY WHOM HER VOTE WAS RECEIVEd 1837 (The Lawbook Exchange, Ltd. 2002) (giving Anthony's attorney's arguments that the court should use the Declaration to interpret the Constitution).

68. See Claude H. Nolen, African American Southerners in Slavery, Civil WAR AND RECONSTRUCTION 156 (McFarland \& Company, Inc. 2001).

69. Id. Senator Charles Sumner was a strong proponent of black civil rights and frequently relied on the Declaration to bolster his legal arguments regarding the meaning of the Constitution and Congress' authority to implement civil rights legislation. See, e.g., Charles Sumner quoted in Jasper B. Shannon, Political Obstacles to Civil Rights Legislation, 275 ANNALS AM. ACAD. POL. \& SoC. SCI. 53, 54 (May 1951) (arguing that the right to vote for blacks was essential because of the Declaration's proclamation that just government is based on consent); Ronald B. Jager, Charles Sumner, the Constitution, and the Civil Rights Act of 1875, 42 NEW ENG. Q. 350, 365 (Sept. 1969) (stating that Sumner considered the Declaration to be a "guiding rule for interpretation of the Constitution").

70. James E. Bond, No EASY Walk to Freedom: Reconstruction and the RATIFICATION OF THE FouRTEENTH AMENDMENT 54, 57-58, 78-81 (Praeger 1997) (citing various instances of proponents of the civil rights movement relying on the Civil Rights Act and the Fourteenth Amendment as authority).

71. Jasper B. Shannon, Political Obstacles to Civil Rights Legislation, 275 ANNALS AM. ACAD. POL. \& SOC. SCI. 53, 58 (May 1951). 
advocated by civil rights activists. ${ }^{72}$

In the political arena during the era of the modern civil rights movement, civil rights were often tied to the Declaration's promise of equality. The civil rights plank in the Republican platform of 1948 relied on the Declaration:

One of the basic principles of this Republic is the equality of all individuals in their right to life, liberty, and the pursuit of happiness. This principle is enunciated in the Declaration of Independence and embodied in the Constitution of the United States; it was vindicated on the field of battle and became the cornerstone of this Republic. This right of equal opportunity to work and advance in life should never be limited in any individual because of race, religion, color, or country of origin. ${ }^{73}$

In addition, President Harry Truman referred to this promise of equality in a commencement address he delivered at Howard University:

Our country is founded on the proposition that all men are created equal. This means that they should be equal before the law. They should enjoy equal political rights. And they should have equal opportunities for education, employment, and decent living conditions. This is our belief, and we know it is right. We know it is morally right. ...

Our Federal Government must live up to the ideals professed in the Declaration of Independence and the duties imposed upon it by the Constitution. The full force and power of the Federal Government must stand behind the protection of rights guaranteed in the Federal Constitution. ${ }^{74}$

Likewise, civil rights leaders argued that the Declaration contained the nation's founding ideals. Martin Luther King, Jr., considered the Declaration of Independence to be an "unparalleled document proclaiming 'profoundly and eloquently the sacredness of human personality."

72. See generally, Joseph H. Taylor, The Fourteenth Amendment, the Negro, and the Spirit of the Times, 4581 J. NEGRO HIST. (Jan. 1960) (describing the evolution of the Fourteenth Amendment in Supreme Court decisions and its basis as the Court's means of disavowing the separate but equal doctrine).

73. Shannon, supra note 71 , at 53, 58 .

74. President Harry S. Truman, Commencement Address at Howard University (June 13, 1952), available at http://www.presidency.ucsb.edu/ws/index.php?pid=14160 \&st $=$ \&st $1=$.

75. Mary Frances Berry, Vindicating Martin Luther King, Jr.: The Road to a Color- 
speeches and writings. For example, when a group of black and white students demonstrated against department store lunch counter discrimination, King compared the actions of those students to those of America's Founders: ${ }^{.76}$

A revolution is occurring in both the social order and the human mind. One hundred eighty-four years ago a bold group of men signed the Declaration of Independence. If their struggle had been lost they had signed their own death warrant. Nevertheless, though explicitly regretting that King George had forced them to this extreme by a long "train of abuses," they resolutely acted and a great new society was born. The Negro students, their parents, and their allies are acting today in that imperishable tradition. ${ }^{37}$

King saw the students as acting within the same revolutionary tradition as America's Founding Fathers. ${ }^{78}$

Given the references to the Declaration by influential civil rights proponents, it is clear the civil rights movement still looked to the Declaration for inspiration and support. But when compared to the references by Radical Republicans during Reconstruction, it is also clear that the role played by the Declaration had changed. Modern references to the Declaration were generally made to elicit the nation's founding principles and provide moral and philosophical support to the proposed reforms and/or political programs. ${ }^{79}$ I believe this was because of the adoption of laws that provided more plausible legal claims for civil rights than did the previous appeals to the Declaration. ${ }^{80}$

The Fourteenth Amendment became the primary constitutional vehicle for securing African Americans' civil rights after Reconstruction. ${ }^{81}$ It was meant to establish the freedmen's civil rights more securely than previous legislation, and it provided constitutional authorization for further civil rights legislation to enforce the equality

Blind Society, 81 J. NEGRO HIST. 137, 141 (Winter-Autumn 1996).

76. See A Testament of Hope: The Essential Writings of Martin Luther King, JR. 94, 98 (James Melvin Washington ed., Harper \& Row 1986) [hereinafter A TESTAMENT OF HOPE].

77. Martin Luther King, Jr., The Burning Truth in the South (1960), in A TESTAMENT OF HoPE, supra note 76 , at 98 .

78. In his famous I Have a Dream speech, King used the Declaration as the standard against which to judge contemporary American life and the ideal toward which America should strive. Martin Luther King, Jr., I Have a Dream (1963), in A Testament of HOPE, supra note 76, at 217.

79. A TESTAMENT OF HOPE, supra note 76.

80. See MAIER, supra note 11, at 214 (stating that the Reconstruction Amendments, "in some measure," incorporated the Declaration's principle of equality).

81. See Howard N. Meyer, The Amendment That Refused to Die 56-60 (Chilton Book Co. 1973). 
promised by the Amendment. $^{82}$ Thus, as Fourteenth Amendment jurisprudence developed and civil rights activists began to realize its potential to aid their cause, the need to rely on the Declaration for legal support diminished.

In the legal arena, opponents of segregation viewed the change similarly. In its amicus brief in Sweatt $v$. Painter, the Committee of Law Teachers Against Segregation in Legal Education provided a discussion of the Equal Protection Clause's origin that tied it to the Declaration:

First, analysis of the origins of "equal protection" in American law shows that, in the form of "equality before the law," it was transferred to this country from the French by Charles Sumner as part of his attack on segregated education in Massachusetts a decade before the Civil War, and linked by him with the Declaration of Independence. Popularized by Sumner, it or like phrases became the slogan of the abolitionists, and it passed into the Constitution as an important part of the abolitionists' share of the Civil War victory....

It was one thing, and a very important one, to declare as a political abstraction that "all men are created equal," and quite another to attach concrete rights to this state of equality. The Declaration of Independence did the former. The latter was Charles Sumner's outstanding contribution to American law. . . ${ }^{83}$

Based on this history of the drafting of the Equal Protection Clause, it would be less productive for the civil rights movement to attempt to stretch constitutional jurisprudence to the point of saying that the Declaration is a part of America's constitutional law when one could point directly to a provision of the Constitution which guaranteed "equal protection of the law."

Although adoption of the Fourteenth Amendment largely diminished the need for civil rights activists to refer to the Declaration in their legal arguments, ${ }^{84}$ they continued to utilize it as the American ideal that American law should strive to realize. The briefs submitted in

82. Id. at 56 .

83. Brief for the Committee of Law Teachers Against Segregation in Legal Education as Amici Curiae Supporting Petitioner at 3,11, Sweatt v. Painter, 339 U.S. 629 (1950) (No. 44).

84. See Brief in Support of Petition for Writ of Certiorari to the Supreme Court of the State of Texas at 20, Sweatt, 339 U.S. 629; Brief for the American Veterans Committee, Inc. as Amici Curiae Supporting Petitioner at 21, Sweatt, 339 U.S. 629; Brief for Federal Council of the Churches of Christ in America as Amici Curiae Supporting Petitioner at 7-9, Sweatt, 339 U.S. 629, all of which rely solely on the Fourteenth Amendment. 
Brown v. Board of Education ${ }^{85}$ exemplify this aspirational rather than legal use of the Declaration. One brief began by intoning that our "democratic society is founded on the belief that all men are equal and capable of governing themselves." institutions of government for the purpose of safeguarding their rights of "life, liberty and the pursuit of happiness." ${ }^{.87}$ It went on to connect this ideal to Brown:

A decision outlawing segregation in education on the elementary and secondary level will not only advance the educational opportunities of both whites and Negroes in the South, but it will also give convincing evidence to millions in Asia and Africa that the United States is willing to give more than lip service to the principles on which it is founded. ${ }^{88}$

Thus, the Declaration was referred to in the legal arguments of the modern civil rights movement, but primarily as an expression of the founding principles of America and not as a source of constitutional law.

\section{Pro-life Movement}

As with earlier social reform movements, members of the pro-life movement rely extensively on the Declaration. And similar to those earlier movements, they also use the Declaration for various purposes: most use it to support moral arguments against abortion; some view the Declaration as having a unique role to play in constitutional interpretation; and some argue that the Declaration is itself a source of independently-binding constitutional law. ${ }^{89}$

The majority of references to the Declaration by pro-lifers are moral. Religious leaders, and especially political activists, refer to the

85. 349 U.S. 294 (1955) (No. 1).

86. Brief of American Federation of Teachers as Amicus Curiae at 3, Brown v. Bd. of Educ. of Topeka, Kan. 3, 349 U.S. 294 (1955) (No. 1).

87. Id.

88. Id. at 14; see also Brief of Petitioner (Bolling) at 26, Brown, 349 U.S. 294 (citation omitted):

This Court, in the Cummings case, said at pages 321-322: "The theory upon which our political institutions rest is, that all men have certain inalienable rights-that among these are life, liberty, and the pursuit of happiness; and that in the pursuit of happiness all avocations, all honors, all positions, are alike open to everyone, and that in the protection of these rights all are equal before the law."

89. See Michele Dillon, Religion and Culture in Tension: The Abortion Discourses of the U.S. Catholic Bishops and the Southern Baptist Convention, 5 RELIGION AND AM. CULTURE 159, 169-71 (Summer 1995), Paolo Torzilli, Reconciling the Sanctity of Human Life, the Declaration of Independence, and the Constitution, 40 CATH. LAW. 197, 201-02 (2000), Lewis E. Lehrman, The Right to Life and the Restoration of the American Republic, 38 NAT'L REV. 25, 26 (Aug. 29, 1986). 
Declaration to support their primarily moral and political arguments against abortion. A good example of this is the document, We Hold These Truths: A Statement of Christian Conscience and Citizenship, which was patterned after the Declaration and released on July Fourth. ${ }^{90}$ This Statement was signed by forty-six persons who represented Catholic, Orthodox, and Protestant churches and communities, as well as the leaders of various religious and political organizations. ${ }^{91}$ The signers, quoting the Declaration, "agreed that-whether the question be protection of the unborn, providing for the poor, restoring the family, or racial justice-we can and must bring law and public policy into greater harmony with the 'laws of nature and of nature's God.",92

The Catholic Church has been especially active in the fight against abortion, and Catholic leaders often refer to the Declaration in their efforts to reach the wider culture through moral persuasion. ${ }^{93}$ Catholics, of course, are not the only religious group to refer to the Declaration of Independence in their arguments against abortion. The Southern Baptist Convention, for example, also utilizes the Declaration. ${ }^{94}$

Political leaders also frequently reference the Declaration in their moral arguments against abortion. President Ronald Reagan wrote:

I have no trouble identifying the answer our nation has always given to this basic question [whether to embrace all human life], and the answer that I hope and pray it will give in the future. America was founded by men and women who shared a vision of the value of each and every individual. They stated this vision clearly from the very start in the Declaration of Independence, using words that every schoolboy and schoolgirl can recite. ...95

President Reagan invoked Abraham Lincoln's use of the Declaration to

90. Symposium, We Hold These Truths: A Statement of Christian Conscience and Citizenship, 76 FIRST ThINGS 51-54 (October 1997).

91. Id. at 54.

92. Id.

93. Dillon, supra note 89; see also Testimony of United States Catholic Conference on Constitutional Amendments Protecting Unborn Human Life Before the SubCommittee on Civil and Constitutional Rights of the House Committee on the Judiciary (Mar. 24, 1976), available at http://www.priestsforlife.org/magisterium/bishops/76-0324uscchousecommittee.htm; Testimony of United States Catholic Conference on Constitutional Amendment Protecting Unborn Human Life Before the Sub-Committee on Constitutional Amendments of the Senate Committee on the Judiciary (Mar. 7, 1974), available at http://www.priestsforlife.org/magisterium/bishops/74-03-07ussctestimony. htm.

94. Sarah Jane Head, Abortion, http://www.erlc.com/erlc/article/abortion (last visited Mar. 13, 2006) (citing Larry K Lewis, Critical Issues: What the Bible Teaches ABOUT ABORTION (Southern Baptist Convention Christian Life Commission, 1990)).

95. Ronald Reagan, Abortion and the CONSCiEnCE of the Nation 27 (Thomas Nelson Publishers 1984). 
remind Americans of their heritage of supporting human rights for all people. $^{96}$ This use of the Declaration is also evident in Reagan's Personhood Proclamation, which he issued as President. ${ }^{97}$

While most pro-life advocates confine their use of the Declaration to moral arguments, some look to the Declaration to further their constitutional arguments against abortion. They view the Declaration as the document which declares America's founding principles and consequently utilize it to interpret various provisions of the Constitution.

For example, Paolo Torzilli argues that the Constitution should be interpreted with the aid of the Declaration because it articulated the nation's founding principles. ${ }^{98} \mathrm{He}$ asserts that "the Framers intended that the Constitution protect the tenets set forth in the Declaration of Independence" and that a "fair interpretation of the Constitution should not violate the purpose upon which our Nation was founded." 99 Torzilli then determines that the "privacy rationale" given for abortion "disappears" because abortion "jeopardizes the unalienable right to life." 100 For Torzilli, abortion should be dealt with by appointing judges who will interpret the Due Process Clauses to protect the "unalienable rights" guaranteed in the Declaration. ${ }^{101}$

A prominent pro-lifer, Hadley Arkes, also refers to the Declaration of Independence in his arguments against the constitutionality of legalized abortion. ${ }^{102}$ Arkes bases his arguments on the proposition that the American constitutional order was founded to secure man's natural rights as announced in the Declaration. ${ }^{103} \mathrm{He}$ then shows how the judiciary has abandoned these founding principles in its jurisprudence. ${ }^{104}$

96. Id. at 27-28.

97. See Proclamation No. 5761, 53 Fed. Reg. 1464-65 (Jan. 19, 1988) (invoking the Declaration).

98. Paolo Torzilli, Reconciling the Sanctity of Human Life, the Declaration of Independence, and the Constitution, 40 CATH. LAW. 197, 201-02 (2000).

99. Id. at 201.

100. Id. at 217 .

101. Id. at 225-26. A similar argument was made by Kelly Hollowell. She begins by noting that the Fourteenth Amendment grants "substantial rights to persons." Kelly J. Hollowell, Defining a Person Under the Fourteenth Amendment: A Constitutionally and Scientifically Based Analysis, 14 REGENT U. L. REV. 67, 68 (2001). To define the word "person" for purposes of the Fourteenth Amendment, Hollowell turns to the Declaration. Id. at 72. She makes the historical argument that the Constitution embodied the Declaration's "natural law principles," and hence that a "person" within the meaning of the Fourteenth Amendment should possess the Declaration's unalienable right to life. Id. at $72-74$.

102. See Hadley Arkes, Natural Rights and the Right to Choose 20-26, 44 (2002).

103. See HADley ARKES, BEyond the CONSTITUTION 40-46 (1990) (arguing that the Constitution was the means of implementing the Declaration's principles).

104. For in the course of defending this new "right" to abortion, the [courts] have talked themselves out of the notion of "natural rights" held by Lincoln and the 
Thus, in Arkes' thinking, abortion violates the natural rights of the unborn child which were to be secured by the government as declared in the Declaration. ${ }^{105}$

A minority of pro-lifers are more radical and argue there is no need to appeal to the text of the Constitution at all. They are satisfied that if abortion violates a fundamental right declared in the Declaration, then the procedure itself is unconstitutional. One of the first major proponents of this view was Lewis Lehrman:

Thirteen years ago, in Roe v. Wade, the Supreme Court overthrew the common law of centuries and the statute law of fifty states, authorized abortion on demand, and thereby severed the child-aboutto-be-born from the Declaration of Independence. It was in the Declaration, the organic law of the American Founding, that the Fathers of our country proclaimed the self-evident truths of our fundamental moral and constitutional law.... It was this original charter of the nation that the Supreme Court violated in Roe, without even the mandate of an election or a vote in Congress. ${ }^{106}$

Lehrman considered the Declaration to constitute a law more fundamental to the American Republic than even the Constitution. ${ }^{107}$ A similar argument against abortion is made by Mark Trapp who

American Founders. But that understanding was absolutely necessary to the Constitution in the sense that, without it, one could not give a coherent account of the Constitution or the "rights" it was meant to secure. The partisans of abortion have meant to establish an expansive notion of rights; but the requirements of their own argument have compelled them to evacuate from the logic of "rights" its deepest meaning. In order to defend that right to abortion, they were compelled to reject the deep logic of "natural rights," for that logic would envelop even the child with rights as soon as the child begins to be. The partisans of abortion were driven then to put, in the place of natural rights, a rather diminished version of rights. But with that logic, or with that diminished notion of "rights," the partisans of the "right to abortion" cannot protect any longer my life, my freedoms, my rights, against the most arbitrary takings and restrictions. For the defenders of abortion have removed the moral ground for the definition and defense of any of those rights.

ARKES, supra note 102, at 173; see also id. at 112-46.

105. See also Clarence Thomas, Toward a "Plain Reading" of the Constitution-The Declaration of Independence in Constitutional Interpretation, 30 How. L. J. 983, 984, 986, 991-92, 994 (1987) ("The proper way to interpret the Civil War amendments is as extensions of the promise of the original Constitution which in turn was intended to fulfill the promise of the Declaration.") For a similar discussion, see also Clarence Thomas, The Higher Law Background of the Privileges or Immunities Clause of the Fourteenth Amendment, 12 HARV. J. L. \& PUB. POL'Y 63, 64-68 (1989) (discussing the Privileges and Immunities Clauses and civil rights through the lens of the Declaration of Independence).

106. Lewis E. Lehrman, The Right to Life and the Restoration of the American Republic, 38 NAT'L ReV. 25, 26 (Aug. 29, 1986).

107. Id. at 28; see also Lewis E. Lehrman, The Declaration of Independence and the Right to Life: One Leads Unmistakably from the Other, AM. SPECTATOR, Apr. 1987, at $22,22-23$ (making the same argument). 
claims that the Constitution "was meant to incorporate the principles of the Declaration." 108 Trapp uses history to establish that the Declaration is incorporated into American constitutional law. ${ }^{109}$ For Trapp, the Declaration constitutes fundamental law that the Constitution incorporated, and because the unborn are "created" at conception and abortion violates this "created" human's right to life, it is unconstitutional. ${ }^{10}$

\section{Summary}

In this subsection I have reviewed the changing fortunes of the Declaration through American history. In the immediate aftermath of the Revolution, the Declaration fell out of the public's consciousness only to be resurrected by social reform movements that have used it for a variety of purposes. Below, ${ }^{111}$ I return to this topic and compare use of the Declaration by today's Declarationists to its use by social reformers.

\section{Divergent Modern Claims in Constitutional Interpretation Regarding the Role and Impact of the Declaration}

The amount of scholarly work in the field of constitutional interpretation is staggering-and constantly growing. Despite this enormous outpouring of scholarly effort, most constitutional scholars pay little, if any, attention to the role of the Declaration. As Professor Scott Gerber has noted, the Declaration "is now all but ignored." 12 A short review of the writings of major scholars in the area confirms Gerber's observation. ${ }^{113}$

108. Mark Trapp, Created Equal: How the Declaration of Independence Recognizes and Guarantees the Right to Life for the Unborn, 28 PEPP. L. REV. 819, 831 (2001).

109. See id. at 832-45.

110. Id. at 845 .

111. See infra Part III.B.1.c.

112. GERBER, supra note 1, at 2; see also Carlton F.W. Larson, The Declaration of Independence: A 225th Re-Interpretation, 76 WASH. L. REV. 701, 705 (2001) ("[T]he position of the Declaration of Independence in recent constitutional thought is one of utter and complete irrelevance.").

113. See, e.g., RANDY E. Barnett, Restoring the Lost Constitution: The PRESUMPTION OF LIBERTY (2004) [hereinafter BARNETT] (making no reference to the Declaration); RoBert H. Bork, The Tempting of AMERICA: The Political Seduction OF THE LAW (1990) (making no reference to the Declaration) [hereinafter BORK]; RONALD DWORKIN, FREEDOM's LAW: THE MORAL READING OF THE AMERICAN CONSTITUTION 315 , 318 (1996) [hereinafter DWORKIN, FREEDOM'S LAW] (noting only Justice Thomas' references to the Declaration); RICHARD F. FALLON, JR., IMPLEMENTING THE CONSTITUTION (2001) (making no reference to the Declaration); SCALIA, supra note 7, at 134 (distinguishing between the "practical" Constitution and the "aspiration[al]" Declaration); Keith E. WhitTINGTON, Constitutional InTERPRETATION: TEXTUAL MEANING, ORIGINAL INTENT, AND Judicial ReVIEW (1999) (making no reference to the 
Scholars of all different stripes-both originalists and nonoriginalists ${ }^{114}$ - come to varying conclusions regarding the role the Declaration should play in constitutional interpretation.

1. Divergent Scholarly Claims Regarding the Role of the Declaration in Constitutional Interpretation

\section{a. No Role}

The vast majority of scholars, including the vast majority of originalist scholars, do not include any unique role for the Declaration in constitutional interpretation. Leading originalists, such as Justice Scalia, ${ }^{115}$ Robert Bork, ${ }^{116}$ Randy Barnett, ${ }^{117}$ and Keith Whittington, ${ }^{118}$ all find no special role for the Declaration. Other constitutional scholars who are not (or at least not entirely) originalists, such as Bruce Ackerman, ${ }^{11}$ Justice Breyer, ${ }^{120}$ Ronald Dworkin, ${ }^{121}$ John Hart Ely, ${ }^{122}$ Richard Fallon, ${ }^{123}$ and Larry Kramer, ${ }^{124}$ likewise do not find a role for the Declaration. ${ }^{125}$

Declaration).

114. For a short explanation of the differences between originalists and nonoriginalists, see Lee J. Strang, An Originalist Theory of Precedent: Originalism, Nonoriginalist Precedent, and the Common Good, 36 N.M. L. REV. 419, 424-28 (2006) [hereinafter Strang Originalist].

115. See SCALIA, supra note 7.

116. See BORK, supra note 113 (omitting discussion of the Declaration within constitutional analysis).

117. See BARNETT, supra note 113 (omitting discussion of the Declaration within constitutional analysis).

118. See WhitTington, supra note 113 (omitting discussion of the Declaration within constitutional analysis).

119. See Bruce Ackerman, We The People: Foundations (1991) (finding the Declaration plays no special role in modern constitutional analysis).

120. See StePhen Breyer, ACtive Liberty: INTERPRETING OUR DEMOCratic CONSTITUTION (2005) (omitting discussion of the Declaration within constitutional analysis).

121. See DWORKIN, FREEDOM's LAW, supra note 113; RONALD DWORKIN, LAW'S EMPIRE (1986) [hereinafter DWORKIN, LAW'S EMPIRE] (omitting discussion of the Declaration within constitutional analysis).

122. See John Hart Ely, Democracy and Distrust: A Theory of Judicial REVIEW (1980) (finding the Declaration plays no special role in modern constitutional analysis).

123. See Fallon, supra note 113 (omitting discussion of the Declaration within constitutional analysis).

124. See Larry D. Kramer, The People Themselves: Popular Constitutionalism AND JUDICIAL REVIEW 7-8 (2004) (discussing the aspects of modern constitutional interpretation sans the Declaration).

125. Lawrence Tribe only refers twice to the Declaration in his constitutional law treatise. LAWRENCE H. TRIBE, AMERICAN CONSTITUTIONAL LAW 40, 74-75 (3d ed. 2000). 
What arguments do scholars who find no role for the Declaration in constitutional interpretation give for their position? Generally, most give no argument because the Declaration is simply not on their horizon. ${ }^{126}$ Larry Kramer, for example, argues that "the people themselves" should have the "central and pivotal role" in implementing and interpreting the Constitution. ${ }^{127} \mathrm{He}$ describes the Declaration in historical context, as the means of separating from England, but beyond that he does not describe a role for the Declaration in constitutional interpretation. ${ }^{128}$

Ronald Dworkin's method of constitutional interpretation also gives no role to the Declaration. He argues that the proper interpretation of the Constitution must fit our constitutional legal practice-text, history, and precedent-and then justify that practice. ${ }^{129}$ Dworkin does not explicitly address the Declaration and, given the absence of any role for the Declaration in our constitutional legal practice, Dworkin's lack of reference to the Declaration is explainable by the fact that employing the Declaration in constitutional interpretation does not fit our constitutional legal practice.

A few scholars do provide short substantive arguments why the Declaration should not play a role in constitutional interpretation. John Hart Ely has argued that appeals to the natural law ideals said to be contained in the Declaration are misplaced for a number of reasons, including "the critical difference in function" between the Declaration and the Constitution. ${ }^{130}$ The Declaration, according to Ely, was an argument justifying independence of the colonies, while the Constitution was "a frame of government."131 Ely argued that the Constitution did not contain a place for natural law because of its different function and because of the lack of agreement regarding natural law at the time of the

126. See, e.g., ACKERMAN, supra note 119, at 6-7, 142, 213, 216 (explaining his concept of dualist democracy and noting the Declaration in its historical context); BARNETT, supra note 113, at 89-113 (describing his originalist methodology without reference to the Declaration); Randy E. Barnett, James Madison's Ninth Amendment, in The Rights Retained by the People: THe History and MEaning of THE NinTH AMENDMENT 1-51 (Randy E. Bamett ed., 1989) (same); BORK, supra note 113, at 143-60 (explaining his originalist methodology" without noting the Declaration); BREYER, supra note 120, at 3-34 (describing his interpretative "theme" of "active liberty" without noting a role for the Declaration); FALLON, supra note 113, at 4-12 (discussing his view of how the Supreme Court should "implement" the Constitution with no discussion of the Declaration); WHITTINGTON, supra note 113, at 5-14 (explaining his originalist interpretative methodology without reference to the Declaration).

127. KRAMER, supra note 124 , at 8 .

128. See KRAMER, supra note 124, at 6, 36-39, 41 .

129. See, e.g., DWORKIN, FREEDOM's LAW, supra note 113, at 8-12 (applying his fit and justification methodology to the Equal Protection Clause); DWORKIN, LAW'S EMPIRE, supra note 121, at 355-99 (applying his interpretative methodology to the Constitution).

130. ELY, supra note 122, at 49 .

131. Id. 
Framing and Ratification. ${ }^{132}$ Justice Scalia, as noted in the Introduction, is also critical of Declarationist claims because of the different purposes of the documents. ${ }^{133}$

Robert Bork has engaged in more extended debate over the Declaration's role. In a number of smaller writings Bork has argued against Declarationist scholars such as Harry V. Jaffa. In a review of Jaffa's book, Original Intent and the Framers of the Constitution, Bork contended that Jaffa's argument was identical to arguments put forward by his (Jaffa's) liberal antagonists in that both find their "heart's desire" in the Constitution. ${ }^{134}$ Bork maintained that the rights protected in the Constitution are the result, not of natural law theorizing, but rather of the particular historical circumstances and common law history of the United States. ${ }^{135}$ Hence, the references to natural law in the Declaration provide no aid to interpreting the Constitution. ${ }^{136}$ Further, Bork argued that the natural law terms in the Declaration's second paragraph, such as "equal," provide "little guidance for constitutional interpretation." 137 Lastly, Bork put forward the inconsistencies between the Declaration's affirmation of equality and the Constitution's accommodation of slavery, which the southern states required as a condition to the Union. ${ }^{138}$

\section{b. Some Role}

Another, smaller group of scholars gives some role to the Declaration in constitutional interpretation, although just what that role is-and its extent-are often left unclear. The constitutional law casebook edited by Douglas Kmiec, Stephen Presser, John Eastman, and Raymond Marcin devotes a section to the role of the Declaration in constitutional interpretation. ${ }^{139}$ The section entitled "The Declaration of Independence - A Summary of American Fundamental Principle," argues that the natural law principles "embedded within the Declaration have continuing validity." 140 The editors claim that the Declaration's placement in the U.S. Code supports this conclusion, along with the background views of the Framers regarding natural law and the

132. Id.

133. SCALIA, supra note 7, at 134.

134. Robert H. Bork, Original Intent and the Framers of the Constitution: A Disputed Question, National ReVIEW, Feb. 7, 1994 (book review).

135. Id.

136. Id.

137. $I d$.

138. Id.

139. Douglas W. KMiec et al., The AmERican Constitutional Order: History, CASES, AND PHILOSOPHY 100-14 (2d ed. 2004).

140. See id. at 101-14. 
Declaration's relationship to the Constitution. ${ }^{141}$ The editors, however, do not provide guidance as to how, practically, the Declaration should influence constitutional interpretation and instead simply state: "[T]hose who drafted the Constitution thought interpretative reference would continue to be made to the natural law." 142

\section{c. Strong Role ${ }^{143}$}

Likely the strongest scholarly work on the interpretative impact of the Declaration on constitutional interpretation from a Declarationist perspective is, To Secure These Rights, written by Professor Scott Gerber. ${ }^{144}$ Gerber advocates a "liberal originalism" which, like its counterpart "conservative originalism," acknowledges the importance of history to constitutional interpretation. ${ }^{145}$ However, unlike its conservative antagonist, liberal originalism recognizes that the Constitution was written "to establish a form of government that would provide better security for natural rights." ${ }^{146}$ As a result, courts should interpret the Constitution, especially its more abstract or general provisions, ${ }^{147}$ "in light of' natural-rights philosophy."

According to Gerber, the Declaration embodies the natural rights philosophy of John Locke. ${ }^{149}$ This philosophy, in turn, is embodied by

141. See id.

142. Id. at 109. For another ambiguous reference to the Declaration's role see Charles E. Rice, The WinNing Side: Questions on Living the Culture of LifE 327 (1999) ("Although the Declaration is not enforceable as such in the courts, its principles ought to inform our understanding of the purpose of the Constitution and the limits of law.").

143. An interesting recurring motif of scholars who argue that the Declaration should play an explicit role in constitutional interpretation is repeated appeals to President Abraham Lincoln. This reliance on Lincoln occurs early in the genre, see George Anastaplo, The Declaration of Independence, 9 ST. LoUIS U. L.J. 390, 395 (1964) (describing Lincoln as the "most distinguished commentator on the Declaration of Independence"); see also id. at 397 (discussing Lincoln's explanation of the meaning of Declaration's use of "Equal"); id. at 406, and has continued to the present. For example, Scott Gerber cites to and quotes Lincoln regularly. GERBER, supra note 1, at 50-51, 166, 208,245 . At one point, Gerber claims that securing natural rights was the purpose of the Constitution, and then states: "That is the 'original intent' of the Founders." GERBER, supra note 1 , at 6 . To support that proposition, Gerber cites Lincoln. GERBER, supra note 1 , at $6,208$.

144. See GERBER, supra note 1. For a work that simply asserts that "the Declaration was the moral statement that would later become the foundation for the Constitution of the new nation," and builds from that assertion, see NORMAN GEISLER \& FRANK TUREK, LEGISLATING MoRALITY: IS IT WISE? Is IT LEGAL? IS IT POSSIBLE? 20 (1998).

145. See GERBER, supra note 1 , at 6 .

146. Id.

147. Id. at 10 .

148. Id.

149. Id. at $40-56$. 
the Constitution. ${ }^{150}$ As a result, the Constitution is the means to effectuate the end ordained by the Declaration: to secure natural rights. ${ }^{151}$

Gerber does not, however, delineate how a judge "appl[ies] the fundamental moral and political principles on which this nation is based to issues of present-day concern." ${ }^{\text {, } 52}$ Instead, he reviews different provisions of the Constitution and suggests the correct interpretation of the law in those areas "in light of" the Declaration. ${ }^{153}$ For example, Gerber argues that the Equal Protection Clause of the Fourteenth Amendment and the equal protection "component" of the Fifth Amendment "are the Constitution's vehicles through which the Declaration's concept of equality should be implemented."154 Referring back to his "liberal" originalist methodology, Gerber summarily claims that the Equal Protection Clause "was intended to embody the broad principles of equality and natural rights articulated in the Declaration."155 Gerber makes similar, rather conclusory, arguments regarding the rights of "life," "liberty," and the "pursuit of happiness."156 In the context of the death penalty, for instance, Gerber recounts the argument against the constitutionality of the death penalty, and then asserts that the "[n]aturalrights interpretation of the Constitution" affirms the constitutionality of the death penalty. ${ }^{157}$

One cannot discuss the Declarationist position without mentioning Harry Jaffa, who has been the most outspoken-and caustic ${ }^{158}$ proponent of that view. Jaffa has argued that "the principles of the Declaration of Independence are the principles of the Constitution."159 Unfortunately, he never offers more than generalizations why that is the case. Instead, Jaffa asserts that the Declaration "tells us why the political authority of the Unites States is also a moral authority."

150. Id. at 57-92.

151. GERBER, supra note 1, at 58; see also id. at 59 (stating that the "primary goal" of the Constitution "is to provide the institutional means to secure the natural-rights philosophical ends of the Declaration").

152. Id. at 58-59.

153. Id. at $164-95$.

154. Id. at 169.

155. GerBer, supra note 1, at 169; see also Howard Gilman, Scott Douglas Gerber, To Secure These Rights, 16 LAw \& HIST. REV. 424, 425 (1998) (book review) (questioning "Gerber's rapid-fire and cursory application of Locke").

156. GERBER, supra note 1 , at 175-95.

157. Id. at 175-179.

158. See, e.g., Harry V. Jaffa, What Were the "Original Intentions" of the Framers of the Constitution of the United States?, 10 U. PUGET SOUND L. REV. 351, 355, 364, 372-73 (1987) (labeling originalists such as Bork and Chief Justice Rehnquist followers of John C. Calhoun).

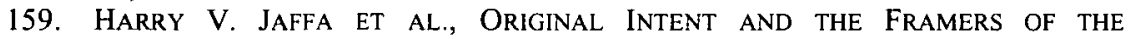
CONSTITUTION: A DISPUTED QUESTION 394 (1994).

160. Id. 
soul of the American Constitution," according to Jaffa, and "our most ennobling principles," are contained in the Declaration. ${ }^{161}$

Jaffa offers a handful of quotes from Jefferson, Madison, and above all Lincoln, to support his contentions. In support of his argument, for example, he relies on statements made by Thomas Jefferson and James Madison in 1825 when they were creating a required reading list for the University of Virginia. ${ }^{162}$ According to Jaffa, Lincoln was the first president to understand the true meaning of the Declaration and to realize that the American system of government rested on the principles espoused therein. ${ }^{163}$

2. Divergent Claims Regarding the Impact of the Declaration in Constitutional Interpretation

In addition to coming to different conclusions regarding what role, if any, the Declaration should play in constitutional interpretation, Declarationist scholars themselves arrive at very different conclusions about the practical impact of the Declaration playing that role. Not surprisingly, the impact of the Declaration falls roughly into liberal and conservative camps. ${ }^{164}$

Declarationist scholars of a liberal bent often argue that, properly interpreted, the Constitution protects rights to abortion, suicide, welfare, homosexual sex, and prohibits differentiation based on gender, class, and sexual orientation, among other bases. ${ }^{165}$ By contrast, Declarationist scholars of a conservative bent tend to argue that the Constitution, as properly interpreted in light of the Declaration, would prohibit abortion, homosexual marriage, euthanasia, affirmative action, and would permit (or require) governmental recognition of God. ${ }^{166}$

161. Id. at 56 .

162. See id. at 22.

163. This claim may seem too strong when one considers that our third president was the Declaration's author, Thomas Jefferson, but Jaffa never addresses this problem.

164. Declarationists such as Gerber are aware of the claim that their view "merely mask[s] the biases of those who employ them." GERBER, supra note 1, at 177.

165. See id. at 164-94 (listing homosexual sex, suicide, and welfare as constitutionally protected activities); Sandefur, supra note 3, at 520-40 (listing freedom from racial discrimination, and freedom for abortion and homosexual sex, among others); see also Debate Between Justice Scalia and ACLU President Nadine Strossen on Constitutional Interpretation (Oct. 15, 2006), available at rtsp://video.c-span.org/15days/ e101506_civilrights.rm?mode=compact (visited Oct. 17, 2006) (arguing that the ACLU's method of constitutional interpretation best effectuates the Declaration's principles). For an interesting twist to the impact of the Declaration in constitutional interpretation, see Mark Tushnet, Taking the Constitution Away From the Courts 129-76 (1999) (arguing that the Declaration and the Constitution, read together, require elimination of judicial review).

166. See Norman Geisler \& Frank Turek, Legislating Morality: Is It Wise? Is 


\section{The Declaration of Independence is One of Many Sources of Original Meaning of the Constitution, and it Therefore Does Not Play a Unique Role in Constitutional Interpretation}

\section{A. Proper Constitutional Interpretative Methodology: Originalism}

I have elsewhere argued that the proper interpretative methodology for our Constitution is originalism. ${ }^{167}$ Originalists argue, based on numerous, sometimes conflicting normative arguments, ${ }^{168}$ that the original meaning of the Constitution is its authoritative meaning. The Constitution's original meaning is the publicly understood meaning of the text of the Constitution at the time it was ratified. To ascertain the original meaning of the Constitution one looks to its text, the use of similar words elsewhere in the Constitution, the Constitution's structure, and the text's historical context: contemporary discussions of the text, official action taken pursuant to the text, and use of similar texts elsewhere in society at the time. Determining the original meaning is, therefore, largely an historical inquiry.

The historical evidence that our society, in ratifying the Constitution, meant for its original meaning to be the binding and authoritative meaning is strong, and I have elsewhere discussed more fully the bindingness of the original meaning today. ${ }^{169}$ This conclusion also has strong scholarly support. ${ }^{170}$ Given our society's commitment to

IT LeGAL? IS IT Possible? 22-23, 115-16, 151-52 (1998) (listing abortion, euthanasia, homosexual activity, slavery, polygamy and illegal drugs as activities that would be prohibited or discouraged); Hollowell, supra note 101, at 72-74 (arguing that abortion is unconstitutional); Adarand Constructors, Inc. v. Pena, 515 U.S. 200, 240-41 (1995) (Thomas, J., concurring) (arguing that the Declaration, through the Equal Protection Clause, outlaws affirmative action).

167. See generally Lee J. Strang, The Clash of Rival and Incompatible Philosophical Traditions Within Constitutional Interpretation: Originalism Grounded in the Central Western Philosophical Tradition, 28 HARV. J.L. \& PUB. POL'Y 909, 982-1001 (2005) [hereinafter Strang Philosophical Traditions] (grounding originalism in the Aristotelian tradition's concept of the common good).

168. See, e.g., BARNETT, supra note 113, at 109-13 (arguing that originalism is justified because the value of "writtenness" it serves, which in turn provides adequate assurance of the legitimacy of the governmental processes established by the Constitution); see SCALIA, supra note 7, at 38-44 (arguing that originalism is the only interpretative methodology that is consistent with our democratically adopted Constitution); see WHITTINGTON, supra note 113, at 152-59 (finding that originalism is the legitimate interpretative methodology because it is "a necessary component" of the Constitution's commitment to popular sovereignty); see Strang Philosophical Traditions, supra note 167, at 982-1001 (grounding originalism in the Aristotelian tradition's concept of the common good).

169. See Strang Philosophical Traditions, supra note 167, at 970-81.

170. See, e.g., JohNATHAN O'NEILl, ORIGINALISM IN AMERICAN LAW AND POLITICS: A CONSTITUTIONAL HISTORY 12-42 (2005) (arguing that originalism was the predominant 
originalism, the Declaration's role in constitutional interpretation is limited to one of the sources of the constitutional text's original meaning.

Originalists further contend that judges are authorized to declare acts of the elected branches unconstitutional, and hence void, only when those acts conflict with the determinate original meaning of the Constitution's text. ${ }^{171}$ Consequently, under our constitutional social ordering, judges may not, generally, directly appeal to natural law norms when adjudicating constitutional cases unless the positive legal materials - the text and original meaning of the Constitution-authorize such an appeal. ${ }^{172}$

Given this commitment to originalism, Declarationists cannot argue that judges should utilize natural law norms found outside of the Constitution's original meaning, such as those said to reside independently in the rights phrase of the Declaration, to adjudicate constitutional cases. Below I will show that the original understanding of the Declaration's role was that it was one source of the Constitution's original meaning and not an independent source of natural rights or legally binding norms.

\section{B. Original Meaning of the Role of the Declaration in Constitutional Interpretation: One Source Among Many}

\section{Historical Evidence}

a. Original Understanding of the Role of the Declaration in Constitutional Interpretation: The "Original" Constitution

In my research of the period of the Framing and Ratification of the Constitution, I uncovered very few explicit statements regarding, and few more implicit references to, the Declaration, and none arguing that the Declaration would play a unique and explicit role in constitutional interpretation. Moreover, I did not uncover any use of the Declaration in

constitutional interpretative methodology during and after Ratification until the early half of the twentieth century); CHRISTOPHER WOLFE, THE RISE OF MODERN JUDICIAL REVIEW: FROM CONSTITUTIONAL INTERPRETATION TO JUDGE-MADE LAW 17 (rev. ed. 1994) (reviewing the history of the Framing and Ratification and concluding that originalist "rules for interpreting a constitution were so generally agreed upon that they were more or less noncontroversial or taken for granted").

171. Lee J. Strang, The Role of the Common Good in Legal and Constitutional Interpretation, 3 U. ST. THOMAS L.J. 48, 69-74 (2005) [hereinafter Strang Common Good].

172. See BARNETT, supra note 113, at 258 (stating that the Constitution's original meaning requires judges to employ natural rights because of the Ninth Amendment and the Privileges and Immunities Clauses). 
arguments for or against a particular interpretation of the Constitution.

Instead, the Framers and Ratifiers used or referred to the Declaration very rarely. When they did use the Declaration, it was for three main purposes: (1) its practical impact as the creator and point of independence from Great Britain, ${ }^{173}$ (2) to bolster an argument for or against the Constitution (or a particular provision in the Constitution) where the disputants agreed on the Constitution's meaning; ${ }^{174}$ and (3) for rhetorical impact. ${ }^{175}$ Historians, such as Pauline Maier, have concluded similarly: "Participants in the extensive debates over the creation and ratification of the federal constitution mentioned the Declaration ... very infrequently and then generally cited its assertion of the people's right to 'abolish or alter their governments' and to found new ones."

While the majority of references to the Declaration regarded its creation of American independence, some of the references to the Declaration during the Framing and Ratification used it to argue for or against the proposed Constitution (or a particular provision in the Constitution) by pointing to positive or negative characteristics of the Constitution (or the provision). What is interesting is that the different sides during ratification generally agreed ${ }^{177}$ on the Constitution's meaning without utilizing the Declaration to arrive at that meaning, and then used the Declaration to argue for or against the Constitution based on that agreed-upon meaning. Review of the historical record, therefore, leads to the conclusion that the Declaration of Independence was one source of the original meaning of the Constitution's text, and that it had no unique role in constitutional interpretation.

During the Constitutional Convention, the delegates referred to the Declaration of Independence infrequently; and the Constitution they created did not incorporate any of the Declaration's language. ${ }^{178}$ The Philadelphia delegates did not make any statements supporting the Declarationist view. ${ }^{179}$ Instead, delegates discussed the Declaration with

173. Detweiler, supra note 15 , at $558,560-61,564$.

174. Id. at 562-64.

175. Id. at $559-60$.

176. MAIER, supra note 11 , at 169.

177. Or they at least did not note any conscious disagreement.

178. Detweiler, supra note 15 , at 562 .

179. See James Madison, Debates in the Federal Convention of 1787: INTRODUCTION, reprinted in 5 DEBATES ON THE ADOPTION OF THE FEDERAL CONSTITUTION in the Convention Held at Philadelphia in 1787 with a Diary of the Debates of THE CONGRESS OF THE CONFEDERATION AS REPORTED BY JAMES MADISON, 110 (Jonathan Elliot ed., Burt Franklin Reprints 1968) (1974) [hereinafter 5 Elliot's DeBATES] (noting that the initial reference to the Declaration is made by Madison in his introduction to his notes from the Constitutional Convention. In these opening remarks, Madison provided a timeline for events leading to the Federal Convention, including the Declaration and the Articles of Confederation). 
reference to its practical impact. For instance, on June 19, 1787, Rufus King and Luther Martin debated the Declaration's impact vis-a-vis independence. ${ }^{180}$ King stated that the states were not complete sovereigns because they could not make war, peace, alliances, or treaties. ${ }^{181}$ Martin responded that the Declaration had instead "placed the thirteen states in a state of nature towards each other." 182 James Wilson rose to King's defense, as did Alexander Hamilton, arguing that the Declaration created an independent nation, not nations. ${ }^{183}$

Later, during a debate on July 7 on the balance of power between the states and the national government, Gouverneur Morris referred to the Declaration as the point of independence and the point at which the first national American government was formed. ${ }^{184}$ Morris then recounted how the newly-independent smaller states had "extorted from the large ones an equality of votes" bringing on the possibility of national dissolution like Germany or the Netherlands. ${ }^{185}$

The state ratification conventions likewise generally focused on the Declaration's role in independence-if the subject of the Declaration came up at all-and did not discuss any role for the Declaration in constitutional interpretation. ${ }^{186}$ "Speakers in the ratifying conventions, although they frequently discussed the rights of the people in relation to government, rarely invoked Jefferson's language of 1776."

In the Pennsylvania ratification convention, for instance, Wilson stated that the Declaration created one national society. ${ }^{188}$ Similarly, Charles Pinckney in the South Carolina convention stated that "the Declaration of Independence... sufficiently refutes the doctrine of the

180. See generally JAMES Madison, DeBates IN the Federal ConVENTION OF 1787, Held at PhILADELPHIA, June 19, 1787, reprinted in 5 Elliot's DEBATES at 212-23.

181. Id. at 212 (remarks of Rufus King).

182. Id. at 213 (remarks of Luther Martin).

183. Id. at 213-14 (remarks of James Wilson and Alexander Hamilton). The only other direct reference to the Declaration during the month of June came on the 28th by Edmund Randolph, who "proposed ... that a sermon be preached at the request of the Convention on the Fourth of July, the anniversary of Independence. . . " Id. at 254.

184. James Madison, Debates in the Federal Convention of 1787, Held at PhiladelPhIA, (July 7, 1787), reprinted in 5 Elliot's Debates, supra note 179, at 28687 (remarks of Gouverneur Morris).

185. Id. at 287.

186. Detweiler, supra note 15 , at 563; see WILLS, supra note 11, at 324 (stating that "[t]he Declaration played almost no part in the debates over ratification of the Constitution").

187. Detweiler, supra note 15 , at 563 .

188. James Wilson, Address at the State Constitutional Ratification Convention for the Commonwealth of Pennsylvania (Dec. 4, 1787), in 2 THE Documentary HISTORY OF the Ratification of the Constitution: Pennsylvania, 472 (Merrill Jensen ed., 1976) [hereinafter 2 DOCUMENTARY HISTORY]. 
individual sovereignty and independence of the several states."189

At another point in the Pennsylvania convention, James Wilson argued that the Declaration recognized "the inherent and unalienable right of the people" $" 190$ to create any form of government they thought conducive to "their safety and happiness." 191 Wilson was responding to the claim that upon independence, sovereignty returned to the states individually. ${ }^{192}$ He did not use the Declaration to argue for or against a particular interpretation of the Constitution.

Delegates to the state conventions also occasionally used the Declaration, not as a means to interpret the Constitution, but to argue for other contested propositions. The delegates would agree on the meaning of a constitutional provision-without recourse to the Declaration-and then argue that the provision was substantively flawed (or sound, as the case may be) and use the Declaration to support that contention.

One example of this is the debate over the absence of a bill of rights. On November 28, 1787, in the Pennsylvania Convention, John Smilie, an opponent of ratification, objected to Wilson's argument that a bill of rights was unnecessary. ${ }^{193}$ Instead, Smilie found a bill of rights indispensable because it established parameters for those in power, ${ }^{194}$ and to support his position he quoted the Declaration for the proposition that America should secure its rights through a bill of rights or else the right to abolish government is "mere sound without substance." 195 Two days later, Thomas Hartley defended Wilson's position by using the Declaration to contend that a bill of rights was unnecessary because "[a]s soon as the independence of America was declared in the year 1776, from that instant all our natural rights were restored to us." 196 Both sides

189. Debates IN South Carolina, 43 (Charleston, A.E. Miller 1831) (1788); see also Larson, supra note 112, at 746-49 (giving examples of this use of the Declaration).

190. James Wilson, Address at the State Constitutional Ratification Convention for the Commonwealth of Pennsylvania (Dec. 4, 1787), in 2 DOCUMENTARY HISTORY, supra note 188 , at 472 .

191. Id. at 473 .

192. Id. at $472-73$.

193. James Wilson, Address at the State Constitutional Ratification Convention for the Commonwealth of Pennsylvania (Dec. 4, 1787), in 2 DOCUMENTARY HISTORY, supra note 188, at 383-84. See John Smilie, Address at the State Constitutional Ratification Convention for the Commonwealth of Pennsylvania (Nov. 28, 1787), in 2 DocUMENTARY HISTORY, supra note 188 , at $385-86$ (rejecting Wilson's argument that a Bill of Rights is unnecessary).

194. John Smilie, Address at the State Constitutional Ratification Convention for the Commonwealth of Pennsylvania (Nov. 28, 1787), in 2 DOCUMENTARY HISTORY, supra note 188 , at $385-86$.

195. Id. at 385 .

196. Thomas Hartley, Address at the State Constitutional Ratification Convention for the Commonwealth of Pennsylvania (Nov. 30, 1787), in 2 DOCuMENTARY History, supra note 188 , at 430. 
in the debate over inclusion of a bill of rights referred to the Declaration, not as an interpretative key, but to argue for or against a bill of rights.

In the Virginia ratification convention, George Mason and James Madison debated the Importation Clause. During the debate, Mason used the Declaration to argue against the constitutional provision whose meaning everyone agreed upon.Mason argued: "No sooner did the revolution take place, than it [slavery] was thought of. It was one of the great causes of our separation from Great-Britain. Its exclusion has been a principal object of this State, and most of the States in the Union." 197 The Importation Clause would have been a logical place to use the Declaration to interpret the Constitution. However, Mason recognized that the Importation Clause had a meaning independent of, and in conflict with the Declaration's.

In the broader public debate surrounding Ratification, references to the Declaration also centered on its impact vis-a-vis independence and not on its role in constitutional interpretation. James Madison, in Federalist 45, echoed the nationalist understanding of the Declaration's impact finding that it created one, independent nation. ${ }^{198}$ Similarly, in an article appearing in the Trenton Mercury on November 6, 1787, entitled A Jerseyman: To the Citizens of New Jersey, the Declaration is referenced as the starting point of the nation's existence. ${ }^{199}$

In an article in the Pennsylvania Gazette, Tench Coxe addressed those who opposed ratification of the Constitution because they feared "state sovereignties, would indeed be finally annihilated." 200 He began

197. George Mason, Address at the State Constitutional Ratification Convention for the Commonwealth of Virginia (June 17, 1788), in 10 THE DOCUMENTARY HISTORY OF THE RATIFICATION OF THE CONSTITUTION: RatifiCation OF THE CONSTITUTION BY THE States: Virginia, 1338 (John P. Kaminski \& Gaspare J. Saladino eds., 1993). Madison responded by claiming that protection of the slave trade was necessary to ensure the southern states' joining the Union. Id. at 1338-39.

198. The FEDERALIST No. 45 (James Madison); see also THE Federalist No. 40 (James Madison) (appealing to the Declaration when he argued that the Federal Convention was justified in creating an entirely new constitution and not merely amending the Articles).

199. A Jerseyman: To the Citizens of New Jersey, TRENTON MERCURY, Nov. 6, 1787, reprinted in 3 THE DOCUMENTARY HISTORY OF THE RATIFICATION OF THE CONSTITUTION: Ratification of the CONSTitution by the States: Delaware, NeW Jersey, Georgia, CONNECTICUT, 146 (Merrill Jensen ed., 1978) [hereinafter 3 DocumENTARY HiSTORY]; see also Letter from Edmund Randolph, The Honorable Speaker of the House of Delegates, to Virginia Legislature (Oct. 10, 1787), reprinted in 15 THE DOCUMENTARY HISTORY OF THE RATIFICATION OF THE CONSTITUTION: COMMENTARIES ON THE Constitution: Public and Private: Volume 3: 18 December 1787 to 31 January 1788, 128 (John P. Kaminski \& Gaspare J. Saladino eds., 1984) [hereinafter 15 DOCUMENTARY HISTORY] (using the Declaration as a reference point to when Americans were united).

200. Tench Coxe, A Freeman I, Pennsylvania GazetTe, Jan. 23, 1788, reprinted in 15 DOCUMENTARY HISTORY, supra note 199, at 455. 
by recalling how American independence had placed the nation in a vulnerable position, prompting the states to form a confederacy to recreate the union dissolved by the Declaration. ${ }^{201}$ According to Coxe, the Declaration dissolved the ties between the colonies and Great Britain as well as the ties among the states themselves. ${ }^{202}$

An unknown author in the Pennsylvania Packet drew on the parallels between the signing of the Declaration and the drafting of the Constitution to advocate its adoption. ${ }^{203}$ The author only noted the Declaration in passing, as the point of independence. By contrast, another commentary, Philadelphiensis VIII, argued against ratification of the Constitution because of the differences between the processes that led to the Declaration and the Constitution. ${ }^{204}$ However, neither used the Declaration for constitutional interpretation.

Joseph Story's Commentaries on the Constitution of the United States $^{205}$ was the major work on the Constitution's history, nature, and meaning in the early nineteenth century. ${ }^{206}$ In it, Story devoted a chapter to how one properly interprets the Constitution. ${ }^{207}$ Story's interpretative methodology was originalist. ${ }^{208}$ Despite providing a fairly in-depth analysis of how to interpret the Constitution, Story did not discuss or refer to the Declaration. ${ }^{209}$ Instead, Story stated that one must "construe them [the Constitution's terms] according to the sense of the terms, and

201. Id.

202. Id. See also Simeon Baldwin, An Oration Pronounced Before the Citizens of New HaVen, JULY 4TH 1788; IN COMMEMORATION OF THE DECLARATION OF INDEPENDENCE AND ESTABLISHMENT OF THE CONSTITUTION OF THE UNITED STATES OF AMERICA (1788) [hereinafter Baldwin], reprinted in 18 THE DOCUMENTARY HISTORY OF the Ratification of the CONSTITUTION: COMMENTARIES on the CONSTITUTION PUBLIC and PRivate: Volume 610 MAY to 13 SePtember 1788, 236 (John P. Kaminski \& Gaspare J. Saladino eds., 1995) [hereinafter 18 DOCUMENTARY HiSTORY] ("The declaration of independence, dissolved the political bands-it cut the nerves of former compacts.").

203. Unknown title, Pennsylvania PACKet, Jan. 14, 1788, reprinted in 15 DOCUMENTARY HISTORY, supra note 199, at 370-71 ("It is agreeable ... to observe how many of the same events and circumstances concur in favour of the New Federal Government, that occurred in favour of the opposition to Great Britain and the declaration of independence in the beginning of the war.").

204. Philadelphiensis VIII, PhILADELPHIA FreEMAN's J., Jan. 23, 1788, reprinted in 15 DOCUMENTARY HISTORY, supra note 199, at 459-61.

205. JOSEPH STORY, COMMENTARIES ON THE CONSTITUTION OF THE UNITED STATES (Carolina Academic Press 1987) (1833).

206. For a discussion on Story's Commentaries, see generally H. Jefferson Powell, Joseph Story's Commentaries on the Constitution: A Belated Review, 94 YALE L.J. 1285 (1985). For a broader explanation of Story's legal views, see generally JAMES MCClellan, Joseph STORY AND THE AMERICAN CONSTITUTION (1971).

207. STORY, supra note 205, at 134-62.

208. Id. at 135-36; see also O'NeILL, supra note 170, at 21-22 (describing Story's method of interpretation as originalist).

209. STORY, supra note 205, at 134-62. 
the intention of the parties, ${ }^{210}$ which one gathers from: the conventional meaning of the text, other uses of the terms in the Constitution, context, the nature of the subject matter, the purpose(s) of the Constitution and the particular term, and the consequences of an interpretation. ${ }^{211}$ The only references Story made to the Declaration occurred elsewhere in his Commentaries and were regarding its historical and legal significance effecting separation from Great Britain. ${ }^{212}$ Under Story's originalist methodology, the Declaration was a source to which one refers in ascertaining the Constitution's meaning, but it did not play a qualitatively more prominent role than other sources. ${ }^{213}$

It is likely true, as Professor Gerber argues, that some Americans during the Framing and Ratification saw the Constitution as the means to protect the rights secured in the fight for independence. ${ }^{214}$ That is why both proponents and opponents of the Constitution periodically used the Declaration to argue that the Constitution did, or did not, fulfill the Declaration's promise. In the article, $A$ Georgian, the author objected to the ratification of the Constitution because it was his "heart's wish to see a federal constitution established agreeable to the principles of republican liberty and independence, and on the basis of a democratical government, meaning that of the people, being that very government

210. Id. at 135.

211. Id.

212. Id. at $88-89$.

213. Story's interpretative methodology followed very closely that explained by William Blackstone. Sir William BlaCkStone, Commentaries on the LawS OF ENGLAND *59-61 (U. Chicago Press 1979) (1769).

Blackstone's interpretative prescriptions were also followed by the first American editor of his Commentaries, St. George Tucker. ST. GEORGE TUCKER, BlaCKSTONE'S COMMENTARIES 60-62 (The Lawbook Exchange, Ltd., 1996) (1803). Like Story, Tucker did not refer to the Declaration when he explained the federal judiciary's role of interpreting the Constitution. Id. at 356-57 (Appendix). Instead, Tucker explained the judiciary's duty to declare void legislative acts contrary to the Constitution and gave a few examples, all tied to specific portions of the Constitution's text. Id. Also like Story, Tucker's references to the Declaration are limited to its role in justifying and creating independence from Great Britain. Id. at 13, 74-75, 173 (Appendix).

James Kent was the author of the treatise, first published in 1827 , that was second only to Story's in early nineteenth century American law. JAMES KENT, COMMENTARIES ON AMERICAN LAW (Rothman Publications 1999) (12th ed. 1873, O.W. Holmes, Jr., ed.). Kent, like Story and Tucker, followed the Blackstonian interpretative prescriptions. Id. at 296, 460-65. And also like Story and Tucker, Kent described constitutional interpretation without reference to the Declaration, $i d$. at $450-55$, and instead noted the Declaration in passing when recounting the history of the United States. Id. at 209-10.

214. GERBER, supra note 1 , at 3, 6, 15, 59; see also Himmelfarb, supra note 2, at 177 78 (supporting Gerber's position). But see Cosgrove, supra note 12, at 134 ("There is, however, very scant evidence from the time of the Framing and Ratification that anyone was thinking of the Constitution as an extension of a political theory announced in the Declaration."). 
intended by our glorious Declaration of Independence."215 A Georgian closed with an appeal to the audience to compare the Constitution to the Declaration so that the reader might find the former inadequate to preserve the intent of the latter. ${ }^{216}$ By contrast, the author of an article in the Pennsylvania Herald viewed the Constitution as preserving the rights espoused by the Declaration:

[W] hen we look forward to the happiness, the power, and the dignity, which the event of that great day [July $4^{\text {th }}$ ] ought to communicate to our posterity; it becomes us, in the pride of our honest triumphs, to provide the means for perpetuating the blessings we enjoy, and to expect with zeal and confidence, from the Fœderal Convention, a system of government adequate to the security and preservation of those rights, which were promulgated by the ever-memorable Declaration of Independency. ${ }^{217}$

For some Americans, the Declaration formed the beginning point of a providential national narrative in which the Constitution played the role of giving "life" to an "expiring nation." 218

However, as I argue below, ${ }^{219}$ even if some Framers and Ratifiers broadly understood the Constitution to secure the natural rights listed in the rights phrase, ${ }^{220}$ Gerber and other Declarationists have failed to show how that goal altered the meaning of the Constitution from what it would have been absent the goal. Gerber fails to point to any instances during the Framing and Ratification where the public understood the

215. A Georgian, GAzetTE OF THE STATE of GeORGIA, Nov. 15,1787 , reprinted in 3 DOCUMENTARY HISTORY, supra note 199, at 236.

216. See id. at 243 ("Thus, fellow citizens, have I pointed out what I thought necessary to be amended in our Federal Constitution. I beg you to call to mind our glorious Declaration of Independence, read it, and compare it with the Federal Constitution; what a degree of apostacy will you not then discover. Therefore, guard against all encroachments upon your liberties so dearly purchased with the costly expense of blood and treasure.").

217. Pennsylvania Herald, July 14,1787 , in 13 The Documentary History of the Ratification of the Constitution: COMmentaries on the Constitution, Public AND PRIVATE, Volume 1, at 165 (John P. Kaminski \& Gaspare J. Saladino eds., 1981).

218. Simeon Baldwin, supra note 202, in 18 DOCUMENTARY HISTORY, supra note 202, at 238; see also William Pierce, An Oration, Delivered at Christ Church, Savannah, on the $4^{\text {th }}$ July, 1788, in Commemoration of the Anniversary of American Independence, in 18 DOCUMENTARY HISTORY, supra note 202, at 249-54 (describing the process of decline and rise that corresponds to the Articles and the Constitution).

219. See infra notes 239-274 and accompanying text (arguing that Gerber has failed to show that the broad purpose of the Framers and Ratifiers-securing the common good-requires one to interpret the Constitution differently than one otherwise would, absent the Declaration).

220. See Jason F. Robinson, Book Note, Gerber's to Secure These Rights, 12 J.L. \& POL. 123, 136 (1995) (arguing that Gerber oversimplifies the history, particularly the question of whether the Framers and Ratifiers saw the Constitution's primary purpose as protecting natural rights). 
Constitution to mean something other than it would have meant absent the Declaration. Instead, as I have shown above, the Framers and Ratifiers rarely used the Declaration, and they did so only as one part of the broader context within which they operated. ${ }^{221}$ Gerber's argument, therefore, fails to show that the Declaration should hold a privileged place in constitutional interpretation.

Originalism was the dominant method of constitutional interpretation at the time of the Framing and Ratification. ${ }^{222}$ The focus of the originalist inquiry is the constitutional text and its context. The fact that some Framers and Ratifiers believed the Constitution secured natural rights is simply one part of the broader constitutional context. There were many instances in which the Framers and Ratifiers debated whether to include a provision in the proposed Constitution, or a provision that was included in the proposed Constitution, where discussion of the Declaration would naturally have lent itself. But this simply did not happen. Instead, they focused their energies on the legal text at issue and its context to ascertain what the provision meant and why the provision was good or bad. For example, in the debate over the scope of federal supremacy in Article VI, both proponents and opponents of the Constitution made arguments from text, history, and political theory. ${ }^{223}$ They did not make arguments grounded in the Declaration even though such arguments would have naturally fit with the topic. For example, elsewhere, Rufus King, Luther Martin, and James Wilson had debated the effect of the Declaration on state sovereignty, ${ }^{224}$ but no similar argument was raised during the discussion of the Supremacy Clause.

Scholars who advocate for a role for the Declaration in constitutional interpretation focus almost exclusively on the first two sentences in the second paragraph, and more specifically, on the reference to the rights of "Life, Liberty and the pursuit of Happiness," what I have been calling the rights phrase. ${ }^{225}$ The vast bulk of the Declaration is not, however, a natural law document. Instead, the body of the Declaration is a list of violations by the King-not of natural law

221. See supra Part III.B.1.a.

222. See supra Part III.A.

223. See Notes of Debates in the Federal Convention of 1787 Reported by JAMES MADISON at 120-21, 139, 142, 306, 348-53, 381, 390, 517, 532, 626 (Ohio Univ. Press 1966) [hereinafter Notes OF DEBATES]; AKHIL REED AMAR, AMERICA'S CONSTITUTION: A BIOGRAPHY 34, 121, 178-79, 190, 299-307 (2005).

224. See NOTES OF DEBATES, supra note 223, at 152-53.

225. DECLARATION OF INDEPENDENCE para. 2 (U.S. 1776); see Larson, supra note 112 , at 711 ("[Declarationist] scholars focus almost exclusively on the second sentence of the Declaration."). 
norms-but of the conventional rights of Englishmen. ${ }^{226}$ As Professor John Reid has noted, the Declaration "did not, in a single instance, accuse George III of violating a natural right.,"227 Instead, the Declaration was a "bill of indictment against the king, written in the language of British constitutionalism."228 Consequently, scholars who concentrate on the rights language misplace their focus and distort the meaning of the Declaration.

The Declaration's second paragraph was not the thrust of the Declaration. The Declaration's goal was to establish that King George had repeatedly "injur[ed] and usurp[ed]" the conventional rights of the colonists as Englishmen. ${ }^{229}$ The Declaration's second paragraph was not a comprehensive, well-thought, binding pronouncement of the natural law philosophy of a new nation. ${ }^{230}$ Moreover, none of the Declaration's drafters or signers viewed it as such. Instead, the Declaration was a defense of "ancient liberties and the British constitution from the malefic scheming or corrupt imperial authorities."231 As Pauline Maier has found, "the [Declaration's] original function was to end the previous regime, not to lay down principles to guide and limit its successor."232 Therefore, to use the Declaration's second paragraph as a binding statement of natural law norms is not faithful to the Declaration. ${ }^{233}$

Historian Philip Detweiler has persuasively argued that the Declaration's rights phrase played little role in public debate and discussion after independence, and only slowly came to occupy a more important position. ${ }^{234}$ "[T]he Fathers, although they did not ignore the

226. See ThE DECLARATION OF INDEPENDENCE paras. 3-29 (U.S. 1776).

227. John Phillip REID, CONSTITUtional History OF The AMERICAN Revolution 14 (abr. ed. 1995).

228. Daniel J. Boorstin, The Genius of American Politics 84 (1953).

229. See THE DECLARATION OF INDEPENDENCE paras. 3-29 (U.S. 1776).

230. See WILLS, supra note 11, at 325 (finding that the "men who debated and passed the Declaration ... were not trying to enunciate a new theory of government, to found a nation, or to write a national charter").

231. KRAMER, supra note 124 , at 37

232. MAIER, supra note 11 , at 192.

233. Scholars are divided on why the rights phrase was placed in the Declaration. Some take the view that the rights phrase was intended as a propaganda piece for French consumption. See RUSSELl KIRK, RightS AND DUTIES: REFLECTIONS ON OUR CONSERvative Constitution 56-57 (1997) (the "phrases of the Declaration ... were calculated to wake strong sympathy in France's climate of opinion"). Others, including possibly Jefferson himself, saw the rights phrase simply as a reiteration of what nearly all Americans believed. THE WRITINGS OF ThOMAS JefFERSON 343 (Paul Leicester Ford et al., eds., 1899) (writing that the Declaration was "an expression of the American mind, and to give that expression the proper tone and spirit called for by the occasion"). Still others argue that the Declaration's preface was "designed first and foremost for domestic consumption." MAIER, supra note 11 , at 131.

234. See Detweiler, supra note 15; see also MAIER, supra note 11, at xviii ("In the decade or so after $1815 \ldots$ the document began to assume... quasi-religious 
phrases of the preamble, viewed the Declaration principally as a proclamation of independence."235 As Carlton Larson has noted, it was the "specific charges laid against George III" that, "for the Continental Congress[,] were the most important part of the Declaration." 236 Initially, Americans focused on the Declaration's impact of independence. ${ }^{237}$ Between the 1790s and 1820s, Americans' focus changed to include the Declaration's rights phrase. ${ }^{238}$ As a result, the Declarationists' exclusive focus on the rights phrase is anachronistic.

Professor Gerber has put forth likely the strongest historical argument that the original meaning of the Constitution (or at least some of its provisions) incorporated the Declaration. ${ }^{239}$ He adduces numerous quotes and statements that discuss natural rights generally, and the role of government to protect those rights slightly more specifically, from the Founding and Ratification (and thereafter). ${ }^{240}$ However, Gerber's argument fails for at least three reasons. First, Gerber fails to tie the general belief in natural rights during the Founding and Ratification period $^{241}$ to the Constitution except in the most general way. Second, Gerber's evidence regarding the general belief in natural rights is better explained, in the historical context, as the lingua franca of the period when referring to the purpose of society: securing the common good. And third, Gerber's Declarationist views are anachronistic.

First, Gerber fails to support his claim that the Framers and Ratifiers understood the Constitution to incorporate the Declaration's principles. The lack of direct evidence that the Framers and Ratifiers understood the Constitution to incorporate the Declaration's principles is in part, Gerber asserts, "because the matter was so well settled by the Declaration" (a claim supported by Gerber with reference to the Preamble, which I criticize below). ${ }^{242}$ While many issues were well settled and hence uncontroversial for the Framers and Ratifiers, those issues had the

attributes.").

235. Detweiler, supra note 15, at 557-58.

236. Larson, supra note 112 , at 763.

237. See Detweiler, supra note 15, at 558-61.

238. See id. at 565-67.

239. See GERBER, supra note 1, at 57-92.

240. See id. Randy Barnett, a scholar who shares views on the strong role of natural rights and on originalism similar to Gerber's, does not find that the Declaration plays a unique role in constitutional interpretation. See BARNETT, supra note 113 (making no reference to the Declaration); Randy E. Barnett, James Madison's Ninth Amendment, in The Rights Retained by the People: The History and Meaning of the Ninth AMENDMENT (Randy E. Barnett ed., 1989) (same).

241. See Philip A. Hamburger, Natural Rights, Natural Law, and American Constitutions, 102 YALE L.J. 907 (1993) (surveying beliefs in natural rights during the Founding era).

242. GERBER, supra note 1 , at 63. 
character of being part of deeply embedded norms and practices. For example, I have argued elsewhere that one aspect of "judicial Power" in Article III, which was deeply embedded in this way, was stare decisis. ${ }^{243}$ To support my claim I provided evidence from English and American, past and contemporary, practice and writing. ${ }^{244}$ In this way, I was able to claim legitimately that "stare decisis was part of the background of the [Framers' and Ratifiers'] lawyerly understanding of judicial power.",245

By contrast, Gerber offers no evidence of a practice, past or contemporary, of using the Declaration to interpret the Constitution, or writers advocating the same. Gerber has therefore failed to substantiate his claim that "the matter was ... well settled."246 Others have criticized Gerber as well, finding that the "social, political, and economic circumstances surrounding the drafting of the Constitution become secondary for Gerber, leaving him free to sift the sources for phrases and paragraphs that support his thesis."247

Two statements by one person, James Wilson, are Gerber's most explicit sources ${ }^{248}$ in tying the Declaration to the Constitution in any way. $^{249}$ However, these quotes do not support Gerber's argument. Instead, in the first quote, Wilson did not even refer to the Declaration but instead stated that "peace, freedom, and happiness" are the end of good government. ${ }^{250}$ This may have been a reference to the Declaration, but it could just as easily have been a reference to some other document

243. Strang Originalist, supra note 114 , at 466.

244. Id.

245. Id.

246. See GERBER, supra note 1, at 63.

247. Wendy Ann Semel, Defender of the Natural Rights Faith,105 YALE L.J. 1427, 1431 (1996) (reviewing SCOTT D. GERBER, To SECuRE THESE RigHTS: THE DECLARATION OF INDEPENDENCE AND CONSTITUTIONAL INTERPRETATION (1995)).

248. Gerber himself recognizes the unique nature of these quotes for his purposes. Gerber writes: "Wilson specifically refers to the Constitution as a 'means' to secure the philosophical "ends' of the Declaration") in one instance, and that he "went so far as to quote the Declaration," in the other. GERBER, supra note 1, at 83 (emphases added).

249. Here is Gerber's discussion of the two Wilson quotes:

[1] In one of his Pennsylvania ratifying-convention speeches, for example, Wilson specifically refers to the Constitution as the "means" to secure the philosophical "ends" of the Declaration of Independence. [2] In another ratifying-convention speech ... Wilson went so far as to quote the Declaration of Independence at length and then state, "This the broad basis on which our independence was placed; [and] on the same certain and solid foundation this system [the Constitution] is erected."

Gerber, supra note 1, at 83 (citing James Wilson, Speech to the Pennsylvania Ratifying Convention, Nov. 26, 1787, in 2 THE WORKS OF JAMES WILSON 769-70 (McCloskey, ed., 1967) [hereinafter 2 THE WORKS OF JAMES WILSON], and Speech by James Wilson in the Pennsylvania Ratifying Convention, Dec. 4, 1787, in 2 DOCUMENTARY HISTORY supra note 188 , at 473 ).

250. James Wilson, Speech to the Pennsylvania Ratifying Convention, Nov. 26, 1787, in 2 THE WORKS OF JAMES WILSON, supra note 249, 769. 
(the Virginia Declaration of Rights) or a theorist's writings (Locke), and Gerber gives no support for his interpretation. ${ }^{251}$

Even assuming Wilson did refer to the Declaration, he was simply making the innocuous claim that the Declaration identified the goals of government while the Constitution created the means to effectuate those ends. Wilson was not advancing Gerber's narrower proposition that the meaning of the Constitution is to be derived (in whole or part) from the Declaration. There is no logical reason-and Gerber points to no historical reason-why the Constitution's connection with the ultimate ends of government requires one to interpret the Constitution differently because of the Declaration (at least when the Constitution's meaning is determinate). In fact, the historical evidence shows, as Professor Jack Rakove has argued, that Americans at the time of the Framing and Ratification understood the "distinction... between fundamental principles of government... and the actual forms that any individual government could take., 252

One way to show the lack of a necessary connection between the goals of the Framers and Ratifiers and the meaning of the Constitution is to assume that the Declaration's rights phrase is incorrect and to note the impact on the meaning of the Declaration. Assume that, for example, government need not rest on consent. The incorrectness of the rights phrase would not alter the legal effect of the Declaration because the legal command of independence is not related to or dependent upon the precatory language in the rights phase. ${ }^{253}$ Similarly, even if securing the rights proclaimed by the Declaration was the goal of the Constitution, that goal has no necessary bearing on the meaning of the Constitution's text. $^{254}$

251. For a statement similar to Wilson's, made in the Virginia ratification convention, see 3 Jonathan Elliot, The Debates in the Several State Conventions, on the ADOPTION OF THE FEDERAL CONSTITUTION, AS RECOMMENDED BY THE GENERAL Convention at Philadelphia in 1787586 (2d ed. 1968) (George Wythe) ("To perpetuate the blessings of freedom, happiness, and independence, he demonstrated the necessity of a firm, indissoluble union of the states."). Like Wilson's statement, Wythe's does not quote the Declaration.

252. Jack N. Rakove, Original Meanings: Politics and Ideas in the Making of THE CONSTITUTION 19 (1996).

253. See O'NEIL, supra note 5, at 239 (giving a similar example).

254. A more concrete example of this lack of connection is the Constitution's Preamble. It contains language similar to the rights phrase-language which the Supreme Court has ruled does not provide enforceable legal norms. Jacobson $v$. Massachusetts, 197 U.S. 11, 22 (1905) ("Although the Preamble indicates the general purposes for which the people ordained and established the Constitution, it has never been regarded as the source of any substantive power.... Such powers embrace only those expressly granted in the body of the Constitution. ... Although, therefore, one of the declared objects of the Constitution was to secure the blessings of liberty to all under the sovereign jurisdiction and authority of the United States, no power can be exerted to 
An example of the lack of necessary connection between the meaning of a legal text and the purposes or goals of the text's creator(s) can be found in hypothesizing an agricultural subsidy bill. ${ }^{255}$ Assume that the bill's sponsor, a senator from an agricultural state, publicly declares that the purpose of the bill is to decrease farm commodity prices. The senator convinces the public and, more importantly, Congress and the President, and his bill becomes law. It is easy to imagine, at this point, that the senator could desire one goal but create a different effect. He may simply have been mistaken in his understanding of the effect of the law. Perhaps he was ignorant of basic economic principles. Whatever the cause, if the statutory scheme mandates that farmers produce fewer units of a particular product, without reducing demand, the effect of the law will be to increase commodity prices. A court could not override the statutory scheme simply because the statute's impact would be in opposition to the goal of the law's creator(s). This hypothetical illustrates that "[b]oth expectations and motivations [for a text] exist independently of the text and bear only a contingent relationship to it." 256

This type of situation-where the meaning of a law and the goal of the law's creators conflict-is a relatively common occurrence. This occurrence leads to the tension judges sometimes face between their duty to uphold the law and the resultant injustice that will occur. ${ }^{257}$ And this also leads to the concept of equity, where a court will mold, massage or, in some cases, completely disregard the legal text's conventional meaning to reach the equitable result, the result the legislator would have wanted the judge to reach. ${ }^{258}$ These aspects of our legal practice,

that end by the United States unless, apart from the Preamble, it be found in some express delegation of power...."). Instead, the Constitution's body is the only source of such norms. Id.

255. See O'NEIL, supra note 5, at 239 (giving a similar example).

256. Keith E. Whittington, Dworkin's "Originalism": The Role of Intention in Constitutional Interpretation, 62 REV. POL. 197, 211 (2000).

257. This tension that judges feel between doing justice in the case before them and their legal duty is the result of the division in our society between law making and law applying functions. See St. Thomas Aquinas, Summa Theologica I-II, at q. 95, a. 1. (Benzinger Bros. 1947) [hereinafter Summa ThEOLOGICA] (emphases deleted) ("As the Philosopher says (Rhet. i. 1), it is better that all things be regulated by law, than left to be decided by judges.").

258. See generally Church of the Holy Trinity v. U.S, 143 U.S. 457 (1892) (utilizing an equitable interpretation of a federal criminal statute to reach what in the Court's view was Congress' purpose); see alsoARISTOTLE, NiCHOMACHEAN Ethics $1137 \mathrm{~b}$ (D.P. Chase trans. 1947) ("When then the law has spoken in general terms, and there arises a case of exception to the general rule, it is proper, in so far as the lawgiver omits the case and by reason of his universality of statement is wrong, to set right the omission by ruling it as the lawgiver himself would rule were he there present, and would have provided by law had he foreseen the case would arise."); see Strang, Common Good, supra note 171, at 
therefore, bear witness to the fact that there is no necessary connection between a legislator's goal and the conventional meaning of a legal text.

Elsewhere, I have explained how the ultimate ends of the Constitution have a role to play in constitutional interpretation, but only when the Constitution's original meaning is underdetermined. ${ }^{259}$ Gerber, by contrast, appears to envision a role for the ultimate ends of government even when the Constitution's original meaning is determinate. ${ }^{260}$ Keith Whittington has argued that natural law theories of interpretation, where the natural law norms override the determinate constitutional text, "cannot fit with the experience of possessing a written constitution at all."261 In such theories, like Gerber's, the constitutional text is not doing any work. "To point to the natural law foundations held by those who drafted the Constitution, and then seek to access them directly, is to miss the point of the drafting, which was to provide political reminders of and legal force for those moral requirements. ${ }^{262}$ Gerber fails to show how, specifically, the Declaration's principles were incorporated into the Constitution. He simply asserts that constitutional provisions mean what the Declaration means. ${ }^{263}$

The Declaration's role regarding the meaning of any particular provision of the Constitution is an historical question that one cannot answer a priori, as Gerber does. ${ }^{264}$ So the meaning of the Cruel and Unusual Punishment Clause, for instance, depends on its text, the broader structure of the Constitution, and context surrounding adoption of the Clause. The overarching goal of the Framers and Ratifiers may play a role at the margins, for example, when the original meaning is underdetermined, but in those areas where the original meaning is determinate, the ends of government and/or the Declaration's principles have little if any role to play in ascertaining that meaning. ${ }^{265}$

Thus, since the original meaning of the Cruel and Unusual

59-66 (explaining the concept of equity further).

259. See Strang Common Good, supra note 171, at 70-74.

260. In the last chapter of To Secure These Rights, Gerber appears to simply substitute what he understands the Declaration to mean for the constitutional text's original meaning. See Gerber, supra note 1, at 162-95.

261. WHITTINGTON, supra note 113 , at 31 .

262. Id. "Axioms alone," Jack Rakove has noted, "do not solve problems." RAKOvE, supra note 252, at 19.

263. See GERBER, supra note 1, at 162-95; see also Howard Gillman, Scott Douglas Gerber, To Secure These Rights, 16 Law \& Hist. Rev. 424, 424-25 (1998) (book review) (arguing that "Gerber improperly interprets discussions about the judiciary's obligation to protect vested rights - that is, rights vested in positive law, such as contract and property rights--as justification for invoking natural rights.").

264. See GERBER, supra note 1, at 176-78.

265. See Strang Common Good, supra note 171, at 70-74 (explaining this). 
Punishment Clause determinately does not proscribe the death penalty, ${ }^{266}$ the ends of government and/or the Declaration play no role in the analysis to come to that conclusion. But, it may not be clear whether the Clause prohibits, for example, chemical castration. ${ }^{267}$ Regarding this issue, assuming the Clause is underdetermined, the ends of government may have a role to play to determine whether such a punishment violates the Clause.

Gerber makes an argument strikingly similar to one made by Ronald Dworkin when he claims that "many of the most significant provisions of the Constitution are phrased in general terms" that "can be given meaning and life only when they are construed in light of the moral and political principles upon which they are based." 268 But Gerber, being an originalist, simply begs the question: what was the original understanding of the clause in question? Was it "general," and did it require interpretation "in light of . . moral and political principles,"269 or was it more specific? As Whittington has argued, "the founders could well have used 'broad' terms to convey relatively narrow thoughts. 270 Gerber simply asserts that the clauses are "general" and does not provide any of the necessary historical evidence to support his claim. Without historical support for this claim, Gerber's subsidiary account of the role of the Declaration's philosophy also fails.

Regarding the second quote from James Wilson, Gerber states that "Wilson went so far as to quote the Declaration of Independence at length and then state, 'This is the broad basis on which our independence was placed; [and] on the same certain and solid foundation this system [the Constitution] is erected.",271 In context, however, Wilson was arguing that the people have the right "to form either a general government, or state governments, in what manner they please" because popular sovereignty is the "broad basis on which our independence was placed." 272 He was responding to claims that the Constitution would

266. LEONARD W. LEVY, ORIGINS OF THE BILL OF Rights 240 (1999) ("Death itself was an acceptable punishment.").

267. For a sampling of the controversy see, e.g., Bryan Keene, Chemical Castration: An Analysis of California's "Cutting-Edge" Policy Towards Sex Offenders, 49 FLA. L. REV. 803, 811 (1997); L. Spalding, Florida's Chemical Castration Law: A Return to the Dark Ages, 25 FLA. ST. U.L. REV. 117,139 (1998).

268. GERBER, supra note 1, at 7. Compare DWORKIN, FREEDOM's LAW, supra note 113 , at 7 ("Many of these clauses are drafted in exceedingly abstract moral language" so that they "refer to abstract moral principles and incorporate them by reference.").

269. GERBER, supra note 1 , at 7 .

270. WHITTINGTON, supra note 113 , at 184

271. GERBER, supra note 1, at 83 (quoting Wilson Ratification Address, supra note 165 , at 472-73).

272. James Wilson, Address at the State Constitutional Ratification Convention for the Commonwealth of Pennsylvania (Dec. 4, 1787), in 2 DOCUMENTARY HISTORY, supra 
destroy state sovereignty and to "illustrate[e]" his popular sovereignty argument he "beg[ged] to read a few words from the Declaration."273 Wilson was not endorsing the Declarationist position. Instead, as I have argued, ${ }^{274}$ Wilson was simply using the Declaration in the ratification debates to argue for ratification of the Constitution, not what the Constitution meant.

Second, much of the evidence Gerber points to as showing that the Framers and Ratifiers saw the purpose of government as securing natural rights supports an argument I have made elsewhere: that the Constitution was meant to secure the common good. ${ }^{275}$ For example, Gerber's first piece of evidence that the purpose of the Constitution was to preserve natural rights is the Preamble. ${ }^{276}$ Gerber admits that "the protection of the people's natural rights" is "not explicitly stated," but then goes on to argue that "it was certainly well understood," in any event. ${ }^{277}$ Gerber argues that every phrase in the Preamble-if properly understood, of course-supports his argument that the purpose of the Constitution was to secure natural rights. ${ }^{278}$

Even the phrase "promote the general welfare" is stretched by Gerber to mean "secure the people's natural rights."279 Indeed, Gerber concedes that " $[t]$ he 'general welfare' is properly understood as the 'public good' or 'public happiness' of society ... rather than simply as the protection of natural rights."280 Despite this concession, Gerber goes on to assert that, while the Framers "sometimes" distinguished natural rights from the common good, the "principal," though "not the sole" purpose of government was to secure natural rights. ${ }^{281}$ Gerber's only support for this assertion is the non-historical claim that the protection of

note 1880 , at $472-73$.

273. Id. at 472 .

274. See supra notes 191-192 and accompanying text.

275. See Strang Philosophical Traditions, supra note 167, at 959-82; see also JoHN FINNIS, NATURAL LAW AND NATURAL RIGHTS 210-18 (1980) (explaining the relationship between the common good and rights).

276. GERBER, supra note 1 , at 60 .

277. Id. (citing a statement by Edmund Randolph). Even Gerber's quote from Randolph, however, supports the broader claim that natural rights "talk" was the contemporary means of discussing the common good. Randolph, in the quote, argued that a discussion regarding natural rights in the Preamble was improper because the subject matter of the Constitution was a society, not a state of nature. See GERBER, supra note 1 , at 60 .

278. The lengths to which Gerber goes to squeeze the historical evidence from the period into his natural rights framework reminds one of Gerber's own admonition to avoid using a natural law approach simply to "mask" one's own views. See Gerber, supra note 1 , at 163.

279. Id. at 62 .

280. Id.

281. Id. (emphases added). 
individual rights depends on the preservation of political society. ${ }^{282}$ In other words, Gerber claims that the phrase "general welfare" in the Preamble does not mean public good because of his prior philosophical assumption about the relationship between natural rights and the general welfare. Others have likewise noted Gerber's tendency to shoehorn all of the historical evidence into his preconceived "individual[] 'natural rights' Lockean philosophy., 283

Gerber also quotes James Madison in Federalist 43 to support the connection between natural rights and the public good. ${ }^{284}$ But Madison is better understood as affirming the importance of the common good: "the great principle of self-preservation [and] ... the transcendent law of nature and of nature's God ... declares that the safety and happiness of society are the objects to which all political institutions aim."285 The purpose of government, according to Madison, was the happiness of society's members. ${ }^{286}$ Therefore, Gerber has it backwards: Madison argued that government should protect natural rights to ensure effective pursuit of the common good and not, as Gerber asserts, effectively pursue the common good to protect natural rights.

The better explanation for much of the evidence Gerber cites is that the Framers and Ratifiers saw the purpose of government as securing the common good. For example, the Preamble lists a number of components of the common good-unity, justice, domestic peace, international security, and liberty - and refers as well to the summary phrase "general welfare." 287 As Jack Rakove has explained: "On the principles of government, a broad consensus reigned. Government existed for the good of the many, and to protect the liberty, property, and equal rights of the citizen." 288

Lastly, Gerber's Declarationist views are anachronistic. This is because, as explained above, ${ }^{289}$ for at least "the first fifteen years following its adoption,... the Declaration of Independence seems to have been all but forgotten, particularly within the United States, except as the means by which Americans announced their separation from Great

282. Id.

283. See Stephen B. Presser, To Secure These Rights: The Declaration of Independence and Constitutional Interpretation, 14 CONST. COMMENT. 229, 235 (1997) (book review); see also Cosgrove, supra note 12, at 132 (criticizing Gerber for his historical "oversimplification").

284. GERBER, supra note 1 , at 62.

285. The FedERAlist No. 43 (James Madison) (emphasis added).

286. See id.

287. See U.S. CONST., pmbl. This understanding of the Preamble is supported by other facts I have discussed elsewhere; see Strang Philosophical Traditions, supra note 167 , at $959-70$.

288. RAKOVE, supra note 252 , at 19.

289. See Part II.B.1. 
Britain." 290 Given the neglect into which the Declaration fell during the period of Framing and Ratification, it is unlikely that the Framers and Ratifiers meant for the Declaration to play a powerful role in constitutional interpretation. And the evidence I reviewed above shows that they did not. ${ }^{291}$

b. Note on the Original Understanding of the Role of the Declaration in Constitutional Interpretation: The "Reconstructed" Constitution

Most Declarationists, like Gerber, concentrate their historical inquiries on the Framing and Ratification of the Constitution, and do not discuss the Reconstruction era. ${ }^{292}$ My preliminary research into this area has led me to tentatively conclude that, although the evidence from the period is relatively unclear, ${ }^{293}$ it appears that the original understanding of the relationship between the Fourteenth Amendment and the Declaration was that the Declaration was one source of the Amendment's original meaning and that the Declaration did not play a unique role in its meaning. ${ }^{294}$ However, given the space constraints of this Article and the voluminous nature of the evidence from the period, which is itself hotly contested by scholars, ${ }^{295}$ I will reserve for another time definitive comment on the relationship between the Declaration and the Fourteenth Amendment.

c. Subsequent Appeals to the Declaration Brought About by Moral Crises

I explained above how, initially, the Declaration was "all but forgotten," grave moral crisis, arguing that it has great significance for constitutional

290. MAIER, supra note 11 , at $168-69$; see also Cosgrove, supra note 12 , at 135 (coming to this conclusion).

291. See supra Part II.B.1.

292. See generally, e.g., JAMES E. BOND, No EASY WALK TO FrEedOM: RECONSTRUCTION AND THE RATIFICATION OF THE FOURTEENTH AMENDMENT (1997); HOWARD JAY GRAHAM, EVERYMAN'S CONSTITUTION: HistoriCAL EsSAYS ON THE FOURTEENTH AMENDMENT, THE "CONSPIRACY THEORY," AND AMERICAN CONSTITUTIONALISM (1968).

293. That is, relative to the Framing and Ratification of the original Constitution.

294. See AMAR, supra note 223, at 389-90 (arguing that the Declaration was or may have been one source of the rights protected by the Fourteenth Amendment's Privileges and Immunities Clause).

295. Debate over the meaning of the Fourteenth Amendment, and especially Section 1 , is long-standing and the participants have come to wildly divergent conclusions. See GRAHAM, supra note 292, at 159-60.

296. MAIER, supra note 11 , at 168. 
interpretation. ${ }^{297}$ These turns toward the Declaration are understandable. When individuals or societies are faced with a grave moral dilemma, they ask themselves who they are. ${ }^{298}$ In light of the answer to that question, the individual or society can resolve the dilemma. ${ }^{299}$

For instance, persons with a drinking problem may become conscious of their problem and the crisis it has created in their lives. They must then decide if they want to continue as before or cease drinking. $^{300}$ If they wish to cease drinking and join Alcoholics Anonymous they will, through a personal "inventory" as part of the twelve-step process, seek to "restore" themselves through the "remov[al] of defects." "301 Stated differently, they will seek to return to who they are, and from that position, face and hopefully overcome the crisis brought on by alcoholism.

Our society is facing a number of moral crises. On issues such as abortion, the nature of marriage, and euthanasia, our society is deeply divided. Legal scholars and others responding to these dilemmas, like Americans in the past, have turned to the Declaration for answers. The resurgence in Declarationist arguments is likely partially attributable to this phenomenon. As a result, we should be wary of anachronistically attributing to the Framers and Ratifiers the Declarationist view that the Declaration has a unique role in constitutional interpretation because such attribution may say more about us today than it does about the Framers and Ratifiers. This is especially true given the strong historical evidence regarding the relative neglect into which the Declaration fell after the Revolution.

\section{The Constitution Is Inconsistent with the Declaration}

Beyond the contextual historical evidence that the Framers and Ratifiers did not understand the Declaration to play a unique role in constitutional interpretation are the dramatic inconsistencies between the various provisions of the Declaration and the Constitution. These contradictions make it difficult to construct, much less attribute to the Framers and Ratifiers, a theory of constitutional interpretation that gives

297. See supra Part II.B.

298. See Wilfred M. McClay, The Founding of Nations, 161 FIRST THINGs 33, 33-39 (2006) ("As before in our history, our current challenges have forced us to think more deeply and clearly about who and what we are.").

299. Id.

300. When the founders of Alcoholics Anonymous met in 1935 one responded to the other's "convincing ideas" and "soon got sober, never to drink again." ALCOHOLICS ANONYMOUS, A.A. FACT FILE 18 (1956), available at http://www.alcoholicsanonymous.org/en_pdfs/m-24_aafactfile.pdf.

301. Id. at 13 . 
the Declaration pride-of-place. The most glaring instance of this inconsistency is regarding the status of slaves.

The Declaration has the inspiring phrase "all men are created equal." 302 The original Constitution, by contrast, accommodated slavery. ${ }^{303}$ In Article I, $\S 2$, the Constitution provided that slave states would benefit in their congressional representation by counting, for population purposes, "three fifths of all other Persons." 304 The Constitution further accommodated slavery by helping slave masters recover escaped slaves through the Fugitive Slave Clause. ${ }^{305}$ Moreover, the Constitution prohibited Congress, until at least 1808, from eliminating the supply of new slaves by ending the slave trade. ${ }^{306}$ The Constitution's accommodation of slavery and the denial of equality it entailed make it very difficult, if not impossible, to non-arbitrarily interpret the Constitution through the lens of the Declaration. ${ }^{307}$

Even were one to assume that one could non-arbitrarily interpret the Constitution in light of the Declaration, one would still have to explain how the practice of slavery with its gross denial of equality existedindeed, flourished-under the Constitution until it was ended through the Civil War. Gerber recognizes that slavery "is in direct contradiction with the Declaration's concept of equality" and that "slavery continued as an uneasy compromise" under the Constitution until the Thirteenth Amendment. ${ }^{308}$ However, he fails to explain why that "direct contradiction" does not fundamentally undermine his argument that the Declaration should play a unique role in constitutional interpretation. The best synthesis Gerber puts forth is that the United States "was not yet ready" to live up to the promise of the Declaration, and that the Declaration "provide[d] the framework for slavery's eventual demise.",309 Gerber argues that, in the case of slavery (among others), the Framers

302. THE DECLARATION OF INDEPENDENCE para. 1 (U.S. 1776).

303. Despite the Constitution's accommodation of slavery, the Constitution was not a pro-slavery document in the sense of a document creating a form of government one of whose purposes was to protect slavery. Arguably, the Constitution granted Congress the power to restrict and maybe even eliminate slavery legislatively through, for example, the Commerce Clause or Congress' power to tax. Congress' ability to restrict or eliminate slavery legislatively was recognized by southerners who, when it became clear that the North would gain a commanding majority in Congress, became more aggressive in their actions to protect slavery, up to and including war.

304. U.S. CONST. art. I, $\S 2$, cl. 3, amended by U.S. CONST. amend. XIV $\S 2$.

305. Id. art. IV, § 2, cl. 3 , amended by U.S. CONST. amend. XIII $\S 1$.

306. Id. art. I, $\S 9$, cl. 1 .

307. See O'NEIL, supra note 5, at 243 (arguing that provisions of the Constitution inconsistent with the Declaration, if anything, repealed the Declaration to the extent of the inconsistency).

308. GERBER, supra note 1, at 164-65.

309. Id. at 166 . 
and Ratifiers "ignored the dictates of natural law for practical reasons." 310

Gerber can only make this claim if the Constitution, properly interpreted, contradicts the Declaration. In other words, the contradictions between the Constitution and Declaration identified by Gerber show that one can, and must, properly interpret the Constitution without reference to the Declaration. First, Gerber determined that the Declaration's concept of equality was inconsistent with slavery. Second, Gerber determined that the meaning of the Constitution permitted slavery. These were two separate and independent determinations, which showed that even Gerber recognizes that the Constitution has a meaning independent of the Declaration. Otherwise, he would be unable to argue that the Constitution conflicted with the Declaration.

Only relatively few, relatively radical abolitionists argued that the Constitution, without necessity of amendment, outlawed slavery. Most who opposed slavery argued instead for a federal law or constitutional amendment to end slavery, recognizing that the law as it stood did not eliminate slavery. The vast majority of Americans, and nearly all lawyers and judges, never questioned the orthodoxy that the Constitution permitted and accommodated slavery. As Robert Cover argued, despite the recognition by many Americans that slavery conflicted with natural law, there was "no constitutional confusion with respect to slavery" because "the courts uniformly recognized a hierarchy of sources of law for application in which 'natural law' was subordinate to constitutions, statutes, and well-settled precedent."311

In fact, the major antebellum case to address the issue, Dred Scott $v$. Sanford, declared the Missouri Compromise unconstitutional, thereby expanding slavery. ${ }^{312}$ Chief Justice Taney's opinion in Dred Scott relied on the Constitution's accommodation of slavery in the Fugitive Slave and Importation Clauses. ${ }^{313}$ Taney argued that slaves of African descent, and descendants of such slaves, were not citizens of the United States as that term was understood in the Constitution, because the Fugitive Slave and Importation Clauses "show clearly that they were not regarded as a portion of the people or citizens of the Government then formed." 314

310. Id. at 164 .

311. Robert M. Cover, Justice Accused: Antislavery And The Judicial Process 34 (Yale University Press 1984) (1975).

312. Dred Scott v. Sanford, 60 U.S. 393, 452 (1856). For more on the case, see William H. Rehnquist, The Supreme Court 53-65 (Vintage 2002) (1987); see also COVER, supra note 311 , at 166-74 (discussing other important antebellum decisions regarding slavery).

313. Dred Scott, 60 U.S. at 411-12 (discussing U.S. ConST., Art. I, § 9, cl. 1, Art. IV, $\S 2, \mathrm{cl} .3)$.

314. Id. at 411 . 
Further evidence that the Constitution did not incorporate the Declaration is that, following the Civil War, few abolitionists argued that the Constitution, properly interpreted in light of the Declaration, abolished slavery without amendment. In fact, even those who held this belief, or something close to it, recognized that their views were idiosyncratic. For example, Senator Charles Sumner ${ }^{315}$ believed that the Declaration was the "guiding rule for interpretation of the Constitution." "316 However, even Sumner recognized that his view was the extreme minority position, and, therefore, worked for passage of statutes and constitutional amendments to secure his aims. ${ }^{317}$

Consequently, Radical Republicans passed federal statutes and constitutional amendments to eliminate slavery. Given the complete victory of the North and the Republicans, one could easily imagine the abolitionists arguing that a properly interpreted-unamendedConstitution outlawed slavery, if that argument were remotely plausible.

The more common view of the relationship between the Declaration and the Constitution at the time of Reconstruction was that the Declaration established the United States and gave the United States its goals, and that the Constitution was one of the means of effecting those goals, though in a flawed manner. Congressman Thaddeus Stevens explained this view:

Sir, our fathers made the Declaration of Independence; and that is what they intended to be the foundation of our Government. If they had been able to base their Constitution on the principles of that Declaration it would have needed no amendment during all time, for every human being would have had his rights; every human being would have been equal before the law.... But it so happened when our fathers came to reduce the principles on which they founded this Government into order, in shaping the organic law, an institution hot from hell appeared among them.... It obstructed all their movements and all their actions, and precluded them from carrying out their own principles into the organic law of this Union. ${ }^{318}$

315. Joseph James has described Sumner as "represent[ing] a very radical position." Joseph B. James, The Ratification of the Fourteenth AmEndment 70 (Mercer University Press 1984).

316. Ronald B. Jager, Charles Sumner, the Constitution, and the Civil Rights Act of 1875, 42 New Eng. Q. 350, 365-66 (1969); see also David Herbert Donald, Charles SUMNER 150-51 (Da Capo Press 1996) (arguing that the federal government had the constitutional authority and moral duty to eliminate slavery through statute or case law); CONG. GLOBE, 36th Cong., 1 st Sess. 2600-2602 (1860) (speech entitled The Barbarism of Slavery by Senator Sumner).

317. See DoNALD, supra note 316, at 132-61 (describing Sumner's efforts).

318. CONG. GloBE, 39th Cong., 1st Sess. 536 (1866). 
3. The Declaration Cannot Offer Sufficient Guidance in Constitutional Interpretation

The Declaration is, at most, one source of original meaning in part because the Declaration cannot, by itself, offer sufficient guidance to judges (and others) interpreting the Constitution. As Carlton Larson has noted, "The Declaration's sonorous phrases seem to provide little guidance in determining the scope of the liberty of which it speaks. ${ }^{.319}$

The Declaration consists of three main parts. The first part is the introduction. It states the purpose of government (to secure rights), recounts how government is legitimated (by consent), lists the natural rights secured by legitimate government (life, liberty, and pursuit of happiness), and gives the conditions under which revolution is justified (when government does not fulfill its purpose). ${ }^{320}$

The introduction sets forth the background against which the second part of the Declaration, the evidence of tyranny by the King, is judged. The body of the Declaration provides evidence for the Declaration's "indictment" $" 321$ of the King. ${ }^{322}$ The list of "evils" visited by King George on the colonists consists of violations of the English constitution and not violations of natural law. ${ }^{323}$ The final two paragraphs of the Declaration announce the separation of the colonies from the mother country. ${ }^{324}$

Portions of the Declaration's second part-the list of regal violations of the English constitution-do have sufficient determinacy and, hence, they may offer valuable insight into constitutional meaning. I discuss the impact of these phrases below in Part III.D. Declarationists, however, focus on the rights phrase, which is too indeterminate to provide guidance to constitutional interpreters. ${ }^{325}$

As I showed above, the rights phrase has been used by scholars of different political stripes to argue for their favored respective-and diametrically opposed-substantive policy goals. ${ }^{326}$ Even advocates of a strong role for the Declaration recognize that most scholars view appeals

319. Larson, supra note 112, at 709; see also George W. Carey, Natural Rights, Equality, and the Declaration of Independence, 3 AVE MARIA L. REV. 45, 60-66 (2005) (discussing the meaning of "unalienable rights" and "all men are created equal").

320. THE DECLARATION OF INDEPENDENCE para. 2 (U.S. 1776).

321. See Anastaplo, supra note 143, at 391-92 (describing the different parts of the Declaration including the central part of the Declaration which is its "cause of action" against the King).

322. The DECLARATION OF INDEPENDENCE paras. 3-30 (U.S. 1776).

323. See supra notes 225-233.

324. THE DECLARATION OF INDEPENDENCE paras. 31 -32 (U.S. 1776).

325. See, e.g., GERBER, supra note 1, at 2; Larson, supra note 112, at 711 ("These scholars [who "emphasize the Declaration"] focus almost exclusively on the second sentence of the Declaration.").

326. See supra Part II.C.2. 
to the Declaration with suspicion, seeing them as "little more than a Rorschach test, into which anything and everything might be read." 327 Scholars arrive at these different conclusions in part because they begin from differing philosophical premises. For instance, regarding the term "Happiness," Declarationist George Anastaplo has argued that it, "properly understood, must be seen in terms of virtue.",328 Anastaplo goes on to explain happiness by discussing Aristotle's Nicomachean Ethics. ${ }^{329}$ Gerber, by contrast, claims that the "right to 'pursue' happiness entails claims one individual has on all others ... to strive to attain his happiness." ${ }^{\text {330 }}$ Gerber grounds his understanding of "Happiness" on the purported "Lockean natural-rights political philosophy" of the Declaration. ${ }^{331}$

This deep, continuing disagreement on the meaning of the terms in the Declaration's rights phrase shows that judges could derive little, if any, interpretative guidance from them. This is because judges would first have to determine which of the competing interpretations of the right the judge finds persuasive-no small feat in itself-and then, within that interpretation, determine how the abstract term applies in the concrete case before him. Both of these determinations are complex and fraught with difficulty because they deal with the meaning of abstract, contested concepts. ${ }^{332}$ In addition, judicial use of contested concepts like "Happiness" would be extremely controversial in the broader society simply because of the fact that the meanings of the concepts are themselves controversial. ${ }^{333}$

In fact, judges have used the terms of the Declaration to reach controversial substantive goals. During the late-nineteenth and earlytwentieth centuries, a period dubbed the Lochner era, ${ }^{334}$ judges

327. Larson, supra note 112 , at 710 ; see also GERBER, supra note 1 , at 162 (stating that he will try to show that the Declaration "is sufficiently determinate to be a practical guide" in individual cases).

328. Anastaplo, supra note 143 , at 409.

329. Id. at 409-10.

330. GERBER, supra note 1 , at 54 .

331. Id. at 28. The right to pursue happiness in the Declaration, for Gerber, led to a constitutional right to basic material needs. Id. at 194.

332. For a discussion of contested concepts, see RONALD DWORKIN, LAW's EMPIRE, supra note 113, at 70-71; RONALD DWORKIN, JUSTICE IN ROBES 145-50 (Harvard University Press 2006) [hereinafter DWORKIN, JUSTICE IN ROBES].

333. For example, dramatic controversy arose and has continued since at least Roe $v$. Wade's purported interpretation of the concept "liberty," 410 U.S. 113 (1973), and has continued through Lawrence v. Texas, 539 U.S. 558 (2003), with its interpretation of the same concept.

334. The label Lochner comes from the (in)famous case of Lochner v. New York, 198 U.S. 45 (1905), in which the Supreme Court struck down a state statute that limited the hourly workweek of laborers in bakeries because it violated the constitutional right to contract. Lochner has come to exemplify the era of economic substantive due process. 
frequently struck down state economic regulation on the basis of an interpretation of the term "liberty" in the Fourteenth Amendment. 335 Judges during this period interpreted "liberty" to include the liberty of contract which states could abridge only for strong reasons. Judges founded this interpretation of the Fourteenth Amendment on, in part, the Declaration's reference to the "pursuit of Happiness." For example, in Butcher's Union Slaughter-house \& Live-Stock Landing Co. v. Crescent City Live-Stock Landing \& Slaughter-house Co., ${ }^{336}$ Justices Bradley and Field both concurred and relied on the Declaration's right to pursue happiness. ${ }^{337}$ And in other cases the Court used the Declaration's rights phrase in its arguments why challenged state legislation was unconstitutional. ${ }^{338}$

Of course, the brute fact of disagreement does not, in and of itself, establish that there is no correct understanding of a legal text, nor does it establish that all interpretations are equally unreasonable. ${ }^{339}$ In the context of contested concepts like "Life," "Liberty," and "pursuit of Happiness," however, debate and not consensus on the meaning of those concepts is the norm, at least in pluralistic societies such as our own. Ronald Dworkin has similarly noted that abstract concepts such as liberty, equality, and justice are subject to "political battles that rage about those ideals." 340 As a result, we should have no expectation that the meaning of the terms in the rights phrase will achieve any sort of workable consensus in our pluralistic society.

Federal judges are no different. They have strongly divergent views on most, if not all, substantive moral and philosophical issues. Take, for instance, "Equality" and the debate over affirmative action. Justices Thomas and Stevens argued in Adarand Constructors, Inc. v. Pena, ${ }^{341}$ that the equality demanded by the Equal Protection Clause mandated opposing conclusions regarding the legality of affirmative action. ${ }^{342}$

335. For an historical review of the economic substantive due process period, see Herbert HOVENKaMP, ENTERPRISE AND AMERICAN LAW: 1836-1937, at 171-204 (1991).

336. 111 U.S. 746, 762 (1884).

337. See id at 762 (Bradley, J., concurring); see also id. at 756-57 (Field, J., concurring); see also Cosgrove, supra note 12, at 114-15 (making the same claim).

338. See Gulf, Colo. \& Santa Fe Ry. Co. v. Ellis, 165 U.S. 150, 160-62 (1879) (relying on the Declaration's phrase "all men are created equal" to rule that a state statute that required only railroad corporations to pay attorneys' fees in tort actions violated the Equal Protection Clause); Cotting v. Godard, 183 U.S. 79, 107 (1901) (relying on the same language to strike down a state regulation of stockyards).

339. See DworkIN, LAW'S EMPIRE, supra note 113, at 76-77 (arguing that in the justification stage of interpretation one must choose that interpretation which is morally best)

340. DWORKIN, JUSTICE IN ROBES, supra note 332, at 143.

341. 515 U.S. 200 (1995).

342. Compare id at 240-41 (1995) (Thomas, J., concurring), with id. at 243-49 
Justice Thomas contended that the equality demanded by the Constitution prohibited both laws "designed to subjugate a race and those that distribute benefits on the basis of race."343 Thomas found that racial classifications designed to aid racial minorities embody a "racial paternalism" that conflicts with the Constitution's "principle of inherent equality" derived from the Declaration. ${ }^{344}$ Justice Stevens, by contrast, rejected any equivalence between laws that classify based on race and benefit a racial minority, and such laws that burden racial minorities: "Remedial race-based preferences reflect the ... impulse ... to foster equality in society."345 Justices Thomas and Stevens were both interpreting and applying the concept of "equality" as embodied in the Fifth Amendment. ${ }^{346}$ Yet, they came to dramatically divergent conclusions because the concept of equality is contested.

Further, consider the right to "Life" proclaimed by the Declaration, in the context of abortion. As noted above, the Declarationists themselves strongly disagree on this issue. ${ }^{347}$ Hadley Arkes, for example, argues that the Declaration proclaims a right to life for all human beings. ${ }^{348}$ Therefore, abortion is not only not a natural right, it is contrary to natural right. ${ }^{349}$ By contrast, fellow Declarationist Timothy Sandefur claims that the Declaration's right to life does not encompass what he calls "single-celled organisms that do not have minds." Gerber takes up yet another position on the meaning of "Life" in the Declaration finding that since "scientists still disagree on when life begins," the "natural-rights political philosophy of the Declaration of Independence cannot determine whether a woman has a constitutional right to choose whether to have an abortion....,351 Declarationists themselves, like judges and the rest of society, come to wildly divergent conclusions on the meaning of the abstract concepts in the Declaration's rights phrase, even on the most important of issues.

The inability of the terms in the Declaration's rights phrase to provide determinate answers to questions of their application to specific circumstances (e.g., in cases) should give one pause before concluding

(Stevens, J., dissenting).

343. Id. at 240 (Thomas, J., concurring).

344. Id.

345. Id. at 243 (Stevens, J., dissenting).

346. See Bolling v. Sharpe, 347 U.S. 497 (1954) (ruling that the Fifth Amendment Due Process Clause has an equal protection component).

347. See supra Part II.C.2 (discussing different views on the impact of the Declaration).

348. See generally Hadley ARKes, Natural Rights and the Right to Choose 5 , 73-111 (2002).

349. See id.

350. Sandefur, supra note 3, at 523.

351. GERBER, supra note 1, at 182-83 (emphasis deleted). 
that the Framers and Ratifiers intended the Declaration to play a unique role in constitutional interpretation, absent strong evidence. Similarly, these problems make it difficult to argue that the concepts "Life," "Liberty," and "pursuit of Happiness," could practically play a role in constitutional interpretation.

This is especially true given the great care the Framers and Ratifiers took in drafting and later in parsing the meaning of the Constitution's text. ${ }^{352}$ As Professor Robert Clinton has argued:

It is difficult to read the debates of the Constitutional Convention without coming to the conclusion that the framers had a finite sense of the meaning of language and that they strove to use language precisely to control the governance of not only the contemporary generation, but also generations to come. Writing in an age before linguistic contextualism, the framers at Philadelphia apparently had a fixed vision of the meanings of the terms they chose. They picked words quite carefully to convey precisely what they meant, no more and no less. Debates over the connotations of constitutional terms reflected a desire to avoid both imprecision and linguistic redundancy. In some cases the framers deliberately chose constitutional terminology to create closed-textured phrasing to prevent future linguistic evasions of their intended meaning. ${ }^{353}$

Given their strong desire to lessen indeterminacy as much as was practicable, it would be odd if the Framers and Ratifiers understood the Constitution to incorporate the abstract, contested terms of the rights phrase. $^{354}$

As I explain below, the Declaration does and should play a role in constitutional interpretation as one source of the Constitution's original meaning. The Declaration is part of the Constitution's historical context and some of the Constitution's provisions, especially those in the Bill of Rights, represent the fulfillment of many of the colonists' goals for a just government. However, the abstract terms in the rights phrase cannot

352. See RAKove, supra note 252, at 342 (arguing that the Framers took great care in crafting a constitutional text that would be as determinate as possible).

353. Robert N. Clinton, Original Understanding, Legal Realism, and the Interpretation of This Constitution, 72 Iowa L. REv. 1177,1190 (1987).

354. It might be the vagueness of the terms in the rights phrase that is a major part of the Declaration's attraction. I showed earlier how different groups have used the Declaration to support their various social reform causes. As Gary Wills has argued:

When the Constitution or some part of the actual government had to be criticized, this reality could be contrasted with the ideal. One could oppose the American government without becoming un-American. After all, what is more American than the Declaration of Independence?

WILLS, supra note 11 , at 358 . 
play such a role.

\section{The Declaration Does Not Play a Privileged Role in Constitutional Interpretation Because of its Own Legal Authority}

1. The Declaration is not Legal in Character Because it does not Order Members of Society Toward Effective Pursuit of the Common Good

The Declaration, and especially its rights phrase, does not, of its own accord, have binding legal authority over judges (or the rest of society). Instead, the Declaration's legal authority ended by the time the Articles of Confederation was ratified. Further, the rights phrase, which is the focus of Declarationist efforts, does not have the character of law. The Declaration therefore does not play a privileged role in constitutional interpretation because of its own legal authority.

Laws have, among other characteristics, ${ }^{355}$ the characteristic of ordering the society of which they are a part toward the common good. ${ }^{356}$ This means that laws guide the conduct of members of society to resolve what John Finnis has labeled the "community's co-ordination problems." 357 Legislators promulgate laws to enable society's members to achieve their own goods, their own end of human flourishing ${ }^{358}$ and to create the background principles against which that flourishing is possible; in other words, the goal of law is to secure the conditions necessary for effective pursuit of the common good. ${ }^{359}$

A good example of law ordering society is civil rights legislation. Congress enacted the 1964 Civil Rights Act $^{360}$ to alter the conditions of

355. See AQuinas, Summa TheOlogiCA, supra note 257 , at I-II, q. 90 , a. 4. (stating that law is "[1] an ordinance of reason [2] for the common good, [3] made by him who has care of the community, and [4] promulgated").

356. See id. at I-II, q. 90, a. 1 ("Law is a rule and measure of acts, whereby man is induced to act or is restrained from acting.").

357. FINNIS, supra note 275, at 276.

358. See Robert P. George, In Defense of Natural Law 44-54, 102-07 (1999), for a discussion of integral human fulfillment through the rightly ordered pursuit of the basic human goods.

359. See FINNIS, supra note 275 , at $154-56$ (describing the common good as "[a] set of conditions which enables the members of a community to attain for themselves reasonable objectives, or to realize reasonably for themselves the value(s), for the sake of which they have reason to collaborate with each other . . . in a community").

360. The Civil Rights Act of 1964, Pub. L. No. 88-352, 78 Stat. 241 (1964). For more background on the 1964 Civil Rights Act, see generally THE CIVIL RIGHTS ACT OF 1964: The Passage of the Law that Ended Racial Segregation (Robert D. Loevy ed., 1997). See also Nick KOTZ, Judgment DAYS: LyndON BAINES JOHNSON, MARTIN LUTHER KING JR., AND THE LAWS THAT CHANGED AMERICA (2005) (discussing the impact of The Civil Rights Act of 1964). 
society that had prevented minorities from reaching their full potential. ${ }^{361}$ The Act spread its antidiscrimination norm across broad swaths of social life including voting, public accommodations, public education, federal programs, and employment. ${ }^{362}$ The Act reordered the relationships of Americans by proscribing relations of racial $^{363}$ domination and prescribing in their place relations based on legally permissible criteria. ${ }^{364}$ So, for example, the owners of restaurants could no longer exclude potential patrons on the basis of race, but the owners could continue to exclude those who failed to dress appropriately or who refused to pay.

The Declaration does not, today, order members of our society toward effective pursuit of the common good. ${ }^{365}$ At most, ${ }^{366}$ the Declaration was legally binding when it effected separation of the colonies from the mother country. ${ }^{367}$ Prior to July $4,1776,{ }^{368}$ the

361. See Lawrence M. Friedman, A History of AmErican LaW 524-25 (3d ed. 2005) [hereinafter FrIEDMAN] (describing the legal oppression of blacks in the South).

362. See The Civil Rights Act of 1964, Pub. L. No. 88-352, 78 Stat. 241 (1964).

363. See id. (among other criteria).

364. See FrIEDMAN, supra note 361 , at 529 ("These laws were more sweeping than any passed since the false dawn of radical reconstruction. And they made a difference.").

365. See Strang Philosophical Traditions, supra note 167, for a review of the history of the United States, including its independence, its first constitution, and the framing and ratification of our current Constitution.

366. In fact, it is arguable whether the Declaration even ordered society on July 4, 1776. The Declaration was not the American colonists' first declaration of independence. On July 2, 1776, the Second Continental Congress declared independence from Great Britain. 5 Journals OF THE CONTINENTAL CONGRESS, 1774-1789 (Worthington C. Ford et al. eds., Washington, D.C. 1904-31). Assuming that the Second Continental Congress had the authority to legislate for the colonies (a fact which is not clear) then it is the July 2 adoption of the Resolution for Independence that reordered the colonies from union with Great Britain to independence. Consequently, it, and not the Declaration of Independence, was-if any document was-the ordering legal declaration of independence.

367. And it may not have done that because the Declaration's legality depended on the authority of the Second Continental Congress to legislate.

368. I have not come to a conclusion whether, in fact (if not de jure), the American colonies became a separate, united society upon independence. One's conclusion will depend on the criteria one uses to determine when a society exists. One could argue, for example, that there existed prior to July 4,1776 , a society because in fact the officiallyBritish colonies were pursuing their own, distinct, common good separately from Great Britain. On this reading of history, the Declaration simply declared de jure what was already de facto the case. See Larson, supra note 112, at 737 (arguing that the Declaration effected the creation of one nation). On the other hand, one could argue that the Declaration, of its own accord, did not create a separate society but instead created thirteen separate societies that did not become one society, coherently pursuing the common good, until some time later. See Forest McDonald, Novus Ordo Seclorum: THE INTELLECTUAL ORIGINS OF THE CONSTITUTION 150 (1985) (offering this view); see also AMAR, supra note 223, at 21-26 (same). There are other possible interpretations of the historical record as well. Regardless of the effect of the Declaration beyond independence from Great Britain, most agree that by the time of the Ratification of the 
American colonies were part of the British Empire, and recognized themselves as such. The colonies were subject to laws passed by Parliament, rule by the King, and to decisions of the British courts. The colonies participated in the common enterprise of the Empire.

The Declaration changed the relationship of the colonies to the rest of the Empire by making the colonies a separate society, separately pursuing the common good of its members. In this changereordering - from unity to separation, the Declaration constituted law. This reading is borne out by the last paragraph of the Declaration which declares the colonies' independence. ${ }^{369}$ Its language is legal in form, unlike the rights phrase. It "declare[s]" that the colonies "are .. Free and Independent States" and that the colonies' ties to Great Britain are "dissolved." 370 This reading of the Declaration's impact is bolstered by the fact that we trace our independence to the Declaration and not to the Treaty of Paris. The Declaration separated the individuals and nongovernmental institutions of the colonies from Great Britain and, importantly, precipitated the creation of permanent governmental apparatuses to oversee the newly-independent states' pursuit of the common good. $^{371}$

Once the separation between the colonies and the Empire was complete, and the newly-independent states were separately pursuing the common good, the Declaration's legal effect was spent. It no longer, of its own accord, ordered the members of American society toward effective pursuit of the common good. The Declaration did not, for instance, change how people acted in 1782. It did not coordinate the activities of Americans because the separation was a past event that later legal norms and social practices superseded.

By 1782, the Articles of Confederation were in force creating a national government that enabled American society to (rather ineffectively) pursue the common good and to do so separately from Great Britain. ${ }^{372}$ The Declaration no longer created or maintained the independence of the United States from Great Britain, as it does not today. If, for example, tomorrow Congress passed and the President signed $^{373}$ a law that stated, "The Declaration of Independence is not in

Constitution, one American society existed.

369. THE DECLARATION OF INDEPENDENCE para. 32 (U.S. 1776).

370. Id.

371. See JACQues Maritain, MAN AND THE STATE $12-19$ (1951) (describing the role of the state as that part of a society which oversees and coordinates the activities of subsidiary institutions toward effective pursuit of the common good); see also FinNIS, supra note 275 , at $147-50$ (describing the complete community).

372. See THE ARTICLES OF CONFEDERATION, art. III (1781) (stating that the purpose of the Confederacy was to secure "their mutual and general welfare").

373. See id. at art. V (One could revise the hypothetical so that the "repeal" of the 
force," the effect would not be immediate reunion with Great Britain. Instead, the law would have no effect because the Constitution would continue in operation and would continue to mandate that the federal government pursue the common good of the United States separately from that of the United Kingdom. ${ }^{374}$

As an analogy, consider a hypothetical law (the Highway Law) passed by a state that required the executive of the state to bring eminent domain proceedings against the private owner of a particular parcel of land (Blackacre) and acquire title to the parcel for the state. The land was to be part of a new highway across the state. The executive brought the action and the court directed the owner to convey title to the state in exchange for just compensation. The exchange then occurred. At this point, the Highway Law has ceased to govern, of its own accord, the relations of members of society because it has had its full effect and now the state owns Blackacre. The Highway Law reordered social relations but does not maintain the relations in their reordered state.

If the state later enacted a law declaring the Highway Law void, it would not change the relationships between the state, Blackacre, and the previous owner because the state's law of property now governed those relations. The state owned Blackacre. The executive could not, absent some additional authorizing provision, return Blackacre to the previous owner; and the previous owner could not simply retake possession (much less ownership) of Blackacre because the state's property law protected the state's ownership of Blackacre by, for example, authorizing the state to bring suit to stop the previous owner from repossessing Blackacre.

The Highway Law hypothetical shows that the legal effect of some legislation is short-lived. Some laws alter the relationships of individuals and entities in society and then cease to have effect because other legal norms (or quasi-legal or nonlegal social practices) apply to the relationships-as altered by the original law-to maintain the social ordering brought about by the original law. To make this even more clear in the Highway Law hypothetical, assume that the state subsequently enacted legislation (the Highway Construction Act) that directed the construction of the highway across Blackacre and created regulations for the operation of the highway (e.g., maintenance regulations, a speed limit, weight and size limits, safety and environmental regulations, etc.).

Persons using the highway across Blackacre after passage of the

Declaration came about through an Article $\mathrm{V}$ federal convention).

374. See U.S. CONST. art. I, $\S 8$ (specifying the scope of Congress' legislative power to pursue the "general Welfare"); id. at art. VI (identifying the Constitution as the "supreme Law of the Land"). 
Highway Construction Act are governed, not by the Highway Law, but instead by the Highway Construction Act. This situation is similar to the relationships of Americans to the Declaration and the Constitution today. The Declaration, like the Highway Law, reordered relations. The Declaration did this through separating the colonies from Great Britain and the Highway Law did this through transferring ownership of Blackacre to the state. But, with the passage of subsequent legislation, both the Declaration and the Highway Law lost their status as the law that was ordering members of society toward the common good. Today, the Constitution shapes the conduct of our society's governments, subsidiary communities, and individual members. Similarly, the Highway Construction Act shaped the actions of persons maintaining and using the highway across Blackacre.

To take another example, assume that two persons who are married seek a divorce. A judge issues a divorce decree. The judge's decree is the legal norm that reordered the relationship of the formerly-married couple, and it continues to order their relationship until a further legal norm enters into the picture. So long as the divorce decree remains in effect, the former spouses may remarry: either each other, or other persons. Upon remarriage, the state's law governing marriage and not the divorce decree would govern (some of) the relations between the former spouses. If the divorce decree ceased to be effective (perhaps through reversal), then the couple's relationship would assume its former shape. For example, if the decree ceased to exist and then one of the former spouses remarried (a third person), that former spouse would have committed bigamy.

The original marriage of the hypothetical spouses is analogous to the relationship of the colonies to the Crown. The marriage laws ordered the relations of the spouses like the laws of Great Britain ordered the relations of the colonies to other parts of the Empire. The divorce decree reordered relations as did the Declaration, by legally separating what was formerly united. The Declaration and the divorce decree continued to govern the relations of the parties until a subsequent legal norm was established. In the case of the United States, the subsequent state constitutions and eventually the Articles of Confederation substituted for the Declaration to maintain the separation from Great Britain, while in the case of the divorcees, subsequent marriage did so. This is the situation today with the Declaration: today, the Constitution, and not the Declaration, orders our society. Part of the social ordering assumed by the Constitution from the Declaration is pursuit of the common good separate from Great Britain.

Reenactment of the Northwest Ordinance by the First Congress, discussed immediately below, is a real-life analogue to the Declaration's 
ceasing to be authoritative and thereby ceasing to order members of society. This is because both were passed by the Second Continental Congress. The actions of the First Congress establish that, under the Constitution's Supremacy Clause, prior national legislation ${ }^{375}$ such as the Declaration and the Northwest Ordinance ceased to be authoritative, absent reenactment under the Constitution, which the Declaration never was.

In sum, the Declaration does not have a unique role in constitutional interpretation because of its own legally authoritative status. As I have shown, any legal authority the Declaration possessed was spent by the time or because of the Articles of Confederation was ratified.

The Declaration's rights phrase is also not a binding legal norm because it does not order members of our society toward the common good. ${ }^{376}$ Unlike the last section of the Declaration, which had legal effect, albeit short-lived, the rights phrase never had legal effect because its language does not change-reorder-the relationships of members of society.

The language of the rights phrase is not imperative; it does not purport to order members of society to do or refrain from doing something. A central case of a law is a speed limit: "Users of the highway shall drive a maximum of 55 m.p.h." ${ }^{377}$ This imperative language orders members of our society to drive at a particular speed so that highway users can safely and efficiently utilize the highways. The language of the rights phrase, by contrast, does not purport to order individuals to do or refrain from doing anything.

Many of us, when driving on the highway at a speed in excess of the speed limit, will alter our speed to comply with the speed limit. If we fail to abide by the speed limit and are fined for this failure, we recognize that our actions were, absent unusual circumstances, illegal, and that the fine was therefore legitimate.

This does not occur with the rights phrase. Members of our society do not intend to act in one manner only to recall the rights phrase and then change their course of conduct. If we feel an obligation to act in accord with the rights phrase, it is different from the obligation we feel to act in accord with legitimate laws such as a highway speed limit.

This is because the rights phrase is hortatory. It exhorts us as individuals and as a society to treat others with, for example, respect. However, if we treat another in a manner contrary to the rights phrase we

375. Not including treaties.

376. See O'Neill, supra note 170 , at $77-78$ (making a similar argument).

377. For a discussion of the "central case" or "focal meaning" see Finnis, supra note 275 , at $9-11$. 
would not characterize our actions as illegal; instead, we would characterize them as immoral. Consequently, while the rights phrase may offer sound moral guidance, it is not a legal command and hence does not play a role in constitutional interpretation because of its own legal authority.

2. Actions of Congress Show that the Declaration is Not a Binding Legal Norm

\section{a. Re-enactment of the Northwest Ordinance}

One particularly strong piece of evidence showing that the Declaration has no independent legal significance is the First Congress' re-enactment of the Northwest Ordinance. ${ }^{378}$ This event shows that the Declaration ceased to have legally operative effect (supposing that it continued to do so after ratification of the Articles) because of the Supremacy Clause's adoption. ${ }^{379}$

The Second Continental Congress enacted the Northwest Ordinance in 1787 , prior to completion of the Federal Convention. ${ }^{380}$ The Northwest Ordinance was the great legislative triumph of the Continental Congress in that it created the structure of western settlement and eventual statehood of Ohio, Michigan, Indiana, Illinois, and Wisconsin. ${ }^{381}$

After the Constitution went into effect, the First Congress, in the eighth act it passed, re-enacted the Northwest Ordinance. ${ }^{382}$ Congress recognized that it had to re-enact the Northwest Ordinance because, absent re-enactment, the Ordinance had no authority under the Constitution. This was because the Supremacy Clause provided that only the Constitution, laws made pursuant to the Constitution, and treaties were the law of the United States. ${ }^{383}$ The First Congress stated in

378. For a review of the history of the Northwest Ordinance, see Denis P. Duffey, Note, The Northwest Ordinance as a Constitutional Document, 95 Colum. L. Rev. 929, 934-41 (1995). For a discussion of the Confederation Congress' ordinances more generally, see Richard P. McCormick, Ambiguous Authority: The Ordinances of the Confederation Congress, 1781-1789, 41 AM. J. LEGAL HIST. 411 (1997).

379. See O'Neill, supra note 170, at 99-100 (making a similar argument).

380. The Northwest Ordinance was enacted on July 13, 1787. See McCormick, supra note 380 at 433 . The Philadelphia Convention ended on September 17, 1787, and the Constitution did not take effect until June 21,1788 , when nine states had ratified it. The last state, Rhode Island, ratified the Constitution on May 29, 1790.

381. See Duffey, supra note 378 , at 968 n.6. The Northwest Territory also contained a portion of what became Minnesota. Id.

382. See An Act to provide for the Government of the Territory North-west of the river Ohio, 1 Stat. 50 (1789).

383. U.S. CONST. art. VI, cl. 2 . 
the Act that "in order that the [Northwest] Ordinance ... may continue to have full effect, it is requisite that certain provisions should be made, so as to adapt the same to the present Constitution of the United States." 384 In other words, with the ratification of the Constitution, all previous legislation by the Second Continental Congress (other than treaties) became inoperable.

The Declaration, like the Northwest Ordinance, was enacted by the Second Continental Congress. It too, absent re-enactment, ceased to have legal force (assuming it retained independent, ongoing legal force after independence, which, I argued above, it did not). Of course, the Declaration was never re-enacted and hence, after ratification of the Constitution, did not have legal force.

The re-enactment of the Northwest Ordinance and the corresponding failure to re-enact the Declaration supports my earlier claim that the Declaration's legal force was spent by the time of, or because of, ratification of the Articles of Confederation. The Northwest Ordinance was needed because it played a vital role in western settlement. By contrast, the Declaration was no longer necessary to maintain independence. That role was assumed by the Constitution under which the First Congress operated.

The re-enactment of the Northwest Ordinance also shows how the First Congress and President Washington understood the relationship between the Constitution and previous legislation. It shows that the original understanding of the Constitution (and specifically the Supremacy Clause) was that the Constitution superseded all preconstitutional legislation (with the exception of treaties) including the Declaration. This understanding supports my argument that the Declaration is a source of the Constitution's original meaning, but that it does not have binding legal significance beyond that.

b. The Declaration's Placement in the United States Code Shows that the Declaration is Not a Binding Legal Norm

Declarationists regularly argue that the Declaration's placement at the beginning of the United States Code under the heading "Organic Laws of the United States," establishes that the Declaration is, in the words of Walter Berns, a "law of the United States." 385 The first title of

384. 1 Stat. 50 (1789) (emphasis added).

385. Walter Berns, Taking the Constitution Seriously 23 (1987). See also KMIEC, supra note 139, at 101 ("[T]he United States Code includes the Declaration of Independence as one of the Organic Laws upon which all statutory law rests."); Trapp, supra note 108, at 834 (arguing that the Declaration's placement at the beginning of the U.S. Code signifies that it "has authority"). 
the U.S. Code begins with a section entitled: "The Organic Laws of the United States of America." 386 The Code then reprints the Declaration, the Articles of Confederation, the Northwest Ordinance, and the Constitution. ${ }^{387}$ Contrary to claims by Declarationist scholars like Berns, the process that brought about placement of the Declaration at the beginning of the U.S. Code provides further evidence that the Declaration does not have a unique role in constitutional interpretation.

The first subject matter codification of federal statutes was the Revised Statutes, enacted in $1878 .^{388}$ The Revised Statutes collected and organized federal statutes that had previously been collected chronologically in the Statutes at Large. ${ }^{389}$ However, after 1878 Congress failed to incorporate later enactments into the Revised Statutes, leading to calls for another codification effort. ${ }^{390}$ These calls bore fruit with the 1926 U.S. Code, which contained the "general and permanent laws of the United States in force December 7, 1925.",391

The present U.S. Code is a compilation of fifty titles, each focused on a particular subject matter. Title I includes general provisions and contains, as its first document, the Declaration. ${ }^{392}$ While its placement at the beginning of the Code could signal that the Declaration has independent legal validity, a look at the background context of the 1926 recodification shows that the opposite is the case.

On June 30, 1926, Congress enacted the law that created the 1926 U.S. Code. ${ }^{393}$ The Act ordered that the "general and permanent laws of the United States" be codified. ${ }^{394}$ In Section 1 of a companion statute, Congress provided for the printing of the Code and other materials. ${ }^{395}$ In

386. U.S.C., at 1 (2000).

387. See id. at 1-54.

388. See An act providing for publication of the revised statutes and the laws of the United States, 18 Stat. 113 (1874) (requiring the codification of the "statutes of a general and permanent nature"); An act to provide for the preparation and publication of a new edition of the Revised Statutes of the United States, 19 Stat. 268 (1877).

389. See 18 Stat. 113 (1874); 19 Stat. 268 (1877).

390. For an earlier effort at recodification, see Joint Resolution Authorizing the printing of the bill to consolidate, codify, revise, and reenact the general and permanent laws of the United States, 41 Stat. 370 (1919).

391. An Act To consolidate, codify, and set forth the general and permanent laws of the United States in force December seventh, one thousand nine hundred and twenty-five, 44 Stat. 1 (1926).

392. See U.S.C., at 1-5 (2000).

393. See 44 Stat. 1 (1926).

394. Id. The Act providing for the creation of the Revised Statutes used essentially the same language to describe the category of laws to be included. See 18 Stat. 113 (1874).

395. See An Act To provide for the publication of the Act to consolidate, codify, and set forth the general and permanent laws of the United States in force December 7, 1925, with index, reference tables, appendix, and so forth, 44 Stat. 778 (1926). 
Section 2 of the companion statute, Congress authorized the House Committee on the Revision of the Laws to prepare for publication "as ancillaries thereto"- that is, ancillary to the general and permanent laws of the United States-a list of materials. ${ }^{396}$ Here is the list:

(1) Preface. (2) Table of Contents. (3) Parallel Reference Tables to the Revised Statutes. ... (4) Parallel Reference Tables to the Statutes at Large... (5) Parallel Reference Tables to the United States Compiled Statutes.... (6) Parallel Reference Tables to the Federal Statutes. (7) The Declaration of Independence. (8) The Articles of Confederation. (9) The Ordinance of 1787. (10) The Constitution of the United States and amendments. (12) Index. ${ }^{397}$

(11) Appendix....

The Sixty-Ninth Congress recognized that the Declaration was not of independent legal significance in a number of ways. First and most importantly, Congress did not include the Declaration among the "general and permanent laws of the United States." "398 Congress explicitly recognized the nonlegal status of the Declaration by labeling it "ancillar[y]."399 This shows that the Declaration, although important historically, culturally, and in other ways, was not legally binding subsequent to the Constitution.

Second, the list of "ancillar[y]" materials includes documents that are clearly nonlegal in nature: the Preface, Table of Contents, and the reference tables were never and never could be legal. ${ }^{400}$ Therefore, the mere fact of placement in the U.S. Code does not, contrary to what some Declarationist scholars have argued, lead to the conclusion that the document is legally authoritative.

Third, the list of "ancillar[y]" materials includes documents that are clearly no longer legally binding. ${ }^{401}$ The list contains the Articles of Confederation and the Northwest Ordinance which were both superseded by the Constitution. Consequently, placement of the Declaration in the U.S. Code does not show that the Declaration retained its legally binding force.

Fourth, the list of "ancillar[y]" materials includes the Constitution which is clearly legally binding regardless of placement in the U.S. Code. ${ }^{402}$ So again, placement in the Code does not necessarily signify that the Declaration is legally binding.

396. 44 Stat. 778 (1926) (emphasis added).

397. Id.

398. See 44 Stat. 1 (1926).

399. See 44 Stat. 778 (1926).

400. Id.

401. Id.

402. See 44 Stat. 778 (1926). 
Lastly, the purpose of printing the Declaration, Articles, Northwest Ordinance, and Constitution, in addition to the general and permanent laws of the United States, was to give pride-of-place to those documents that had a profound impact in shaping our nation. These are the laws that "define and establish [our] government," as Black's Law Dictionary defines organic documents. ${ }^{403}$ By including America's organic laws in the beginning of the Code, Congress followed in the path of the FortyFourth Congress which had also required their inclusion in the earlier Revised Statutes. ${ }^{404}$ Congress' purpose in placing them in the Code was not to identify any continuing legal validity of the documents, but instead to recognize the contributions they had made to our nation's government.

As shown above, the Declaration's placement in the Code does not indicate a judgment by Congress that the Declaration has independent legal significance. On the contrary, I have shown that Congress' actions in codifying federal law support my contention that the Declaration's legal significance comes only through its influence on the original meaning of the Constitution.

\section{Proper Role of the Declaration in Constitutional Interpretation}

The proper role of the Declaration of Independence in constitutional interpretation is as one source of the original meaning of the Constitution's text. As discussed earlier, to arrive at the constitutional text's original meaning, one must look to the Constitution's text, its structure, evidence surrounding ratification on how the text was understood, and the background against which the text was understood including legal, philosophical, and social circumstances. ${ }^{405}$

For example, the Sixth Amendment protects the right to trial by jury in criminal prosecutions. ${ }^{406}$ The right to trial by a jury of one's peers in criminal prosecutions has deep roots in English and American law. ${ }^{407}$ In the period of conflict leading up to the Revolution, the right to a criminal jury trial was one of the rights threatened by the Crown. ${ }^{408}$ The Stamp Act of 1765 provided that admiralty courts, which did not have juries, would be the forum of enforcement. ${ }^{409}$ In addition, the Coercive Acts of

403. BLACK'S LAW DiCTIONARY 1126 (7th ed. 1999).

404. See 19 Stat. 268 (1877) ("That there shall also be included in said edition. ...") (emphasis added).

405. For a short discussion of the use of the Declaration as a source of original meaning by the courts, see Larson, supra note 112, at 717-19.

406. See U.S. CONST. amend. VI.

407. See generally LEVY, supra note 266, at 210-30 (reviewing the history of the double jury system).

408. See id. at 226-27.

409. Id. at 226 . 
1774 provided that trial of some violations of the Act be held in England. ${ }^{410}$

The colonists' response to Crown infringements on the right to a criminal jury trial was strong. ${ }^{411}$ The Stamp Act Congress objected to the Stamp Act's denial of jury trials in criminal cases, and the First Continental Congress protested the same denial by the Coercive Acts. ${ }^{412}$ The Declaration of Independence, approved by the Second Continental Congress, was part of this American reaction to systemic Crown incursion on colonists' rights. ${ }^{413}$ The Declaration declares, as one of the charges against King George III, that he "depriv[ed] us, in many cases, of the benefit of trial by jury.'

Following the Revolution, every state constitution protected the right to a jury trial, and the absence of similar protection in the proposed federal Constitution nearly prevented its ratification. ${ }^{415}$ The famous Federalist concession of a bill of rights to secure ratification led eventually to James Madison's introduction of amendments that became the Bill of Rights, including a provision in the Sixth Amendment protecting the right to a trial by jury in criminal proceedings. ${ }^{416}$

Consequently, the Declaration is one source of the original meaning of the right to jury trial in the Sixth Amendment. The Declaration sheds light on why Madison proposed the Sixth Amendment and points to the common law background of the right. ${ }^{417}$

\section{E. The Declaration's Many Roles}

The short discussion on the proper role of the Declaration in constitutional interpretation in Part III.D is not exhaustive, nor is it

410. Id.

411. Id. at 226-27.

412. Id.

413. See LEVY, supra note 268, at 227.

414. THE DECLARATION OF INDEPENDENCE para. 20 (U.S. 1776).

415. See LEVY, supra note 266, at 227-28.

416. Id. at 230 .

417. Another, somewhat ironic example, of the Declaration's role in constitutional interpretation is its charge that King George had "affected to render the military independent of and superior to the civil power." THE DECLARATION OF INDEPENDENCE para. 14 (U.S. 1776). During the initial stages of the Civil War, Lincoln suspended the writ of habeas corpus to protect Washington, D.C., from Confederate sympathizers. See David Herbert Donald, Lincoln 299 (1995). See also William H. ReHnQuist, All the Laws But One: Civil Liberties IN Wartime 22-23 (1998). John Merryman was imprisoned in Fort McHenry by the Army pursuant to executive order, and Merryman sought release through a writ of habeas corpus. Id. at 26. In his opinion, which ruled that Lincoln did not have the power to suspend the writ, Chief Justice Taney relied on the Declaration's charge that King George had denied civil authority over the military. See Ex Parte Merryman, 17 F. Cas. 144, 152 n.3 (C.C.D. Md. 1861) (No. 9487). 
exhaustive of the other roles the Declaration does and should play. The Declaration is a source of national pride. It has a justly prominent role in our nation's annual celebration of its birth. ${ }^{418}$ The Declaration's language is beautiful. And the Declaration has many legal roles to play, outside of the context of constitutional interpretation. For example, many states date the severance of their common law from England's to the Declaration, ${ }^{419}$ and American citizenship is dated from the Declaration. ${ }^{420}$ This Article in no way downplays the continuing role of the Declaration in many areas of life.

\section{Conclusion}

In this Article, I argued that the Declaration of Independence is one of many sources of the original meaning of the text of the Constitution. First, I laid out the background debate over the role of the Declaration in constitutional interpretation. Then I described how appeals to the Declaration have periodically arisen during times of national moral crisis, such as those over slavery or civil rights. I also detailed how scholars have relied on the Declaration to support dramatically inconsistent claims of political morality and constitutional norm.

Assuming an originalist perspective on constitutional interpretation, $I$ then argued that the historical evidence from the Framing and Ratification of the "original" Constitution shows that the Declaration is simply one source of the original meaning of the Constitution. In addition, I argued that the Declaration is not the "interpretative key" to the Constitution because of the inconsistencies between the two documents, and because the Declaration cannot provide sufficient interpretative guidance. Lastly, I advanced arguments to establish that the Declaration is not independently legally binding. In doing so, I rebutted many of the common Declarationist claims.

418. See Larson, supra note 112, at 750-53 (discussing the early celebrations of Independence Day on July 4).

419. See generally Larson, supra note 112, at 713-21 (discussing the continuing legal roles of the Declaration).

420. See, e.g., Inglis v. Trustees of the Sailor's Snug Harbor, 28 U.S. (3 Pet.) 99, 121 (1830). 
